\title{
Ground-Water Quality in the Red River of the North Basin, Minnesota and North Dakota, 1991-95
}

\author{
U.S. Geological Survey
}

Water-Resources Investigations Report 98-4175

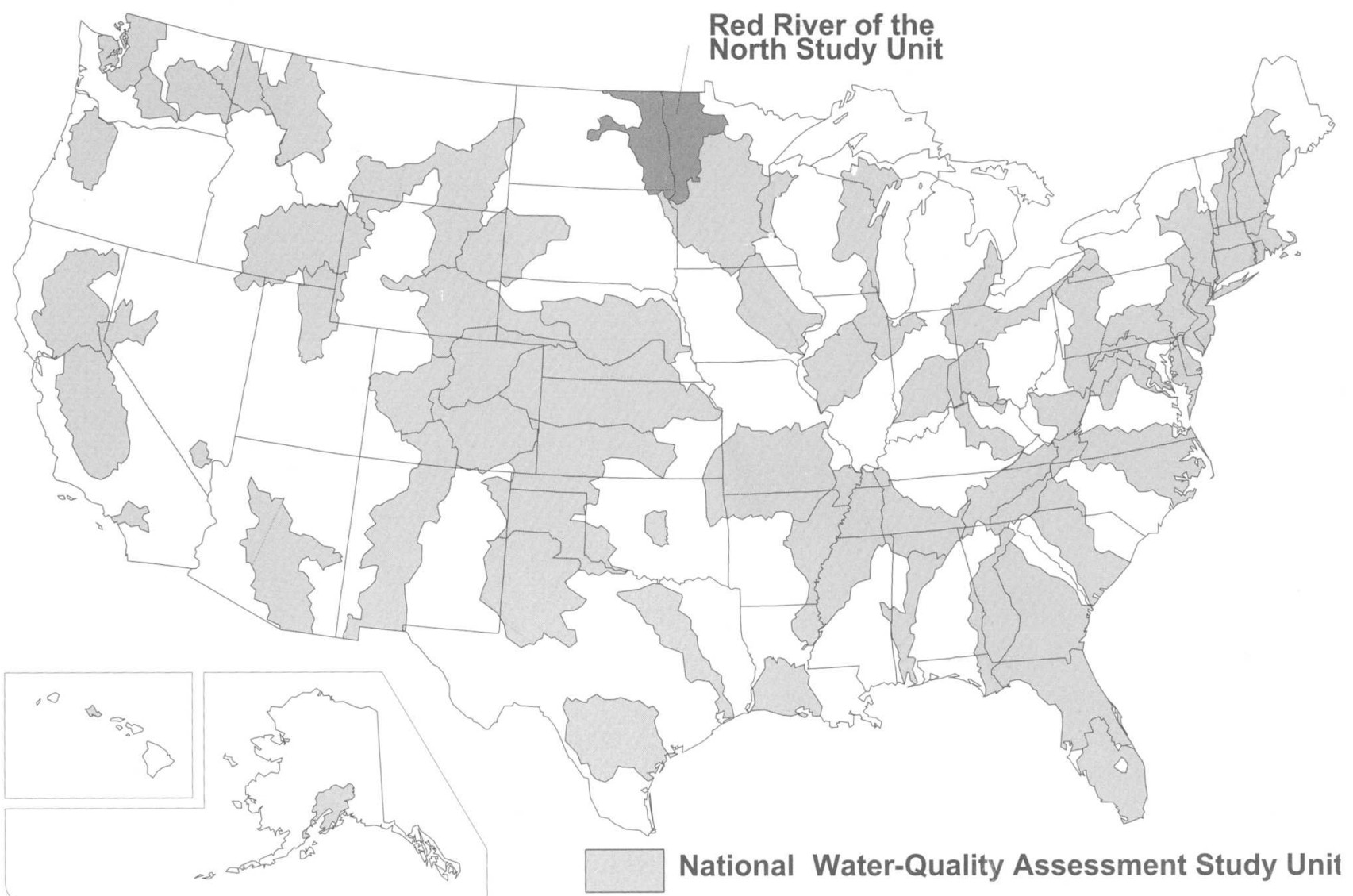

Contribution from the

National Water-Quality Assessment Program 


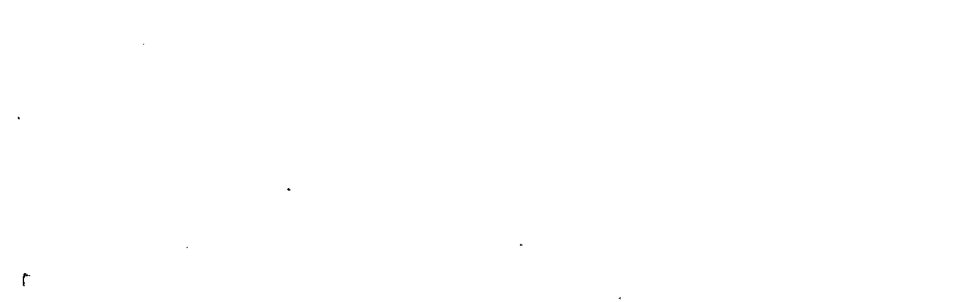

2

? 


\section{Ground-Water Quality in the Red River of the North Basin, Minnesota and North Dakota, 1991-95}

By Timothy K. Cowdery

Water-Resources Investigations Report 98-4175 


\section{U.S. Department of the Interior}

Bruce Babbitt, Secretary

\section{U.S. Geological Survey}

Thomas J. Casadevall, Acting Director

Mounds View, Minnesota, 1998

For additional information write to:

District Chief

U.S. Geological Survey, WRD

2280 Woodale Drive

Mounds View MN 55112

Copies of this report can be purchased from:

U.S. Geological Survey

Branch of Information Services

Box 25286

Federal Center

Denver CO 80225

Information regarding the National Water Quality Assessment Program (NAWQA)

is available on the Internet via the World Wide Web. You may connect to the

NAWQA Home Page using the Universal Resource Locator (URL) at

http://wwwrvares.er.usgs.gov/nawqa/nawqa_home.html

You may also connect to the Red River of the North NAWQA Home Page at

http://wwwmn.cr.usgs.gov/redn/index.html 


\section{Foreword}

The mission of the U.S. Geological Survey (USGS) is to assess the quantity and quality of the earth resources of the Nation and to provide information that will assist resource managers and policymakers at Federal, State, and local levels in making sound decisions. Assessment of water-quality conditions and trends is an important part of this overall mission.

One of the greatest challenges faced by water-resources scientists is acquiring reliable information that will guide the use and protection of the Nation's water resources. That challenge is being addressed by Federal, State, interstate, and local water-resource agencies and by many academic institutions. These organizations are collecting water-quality data for a host of purposes that include: compliance with permits and water-supply standards; development of remediation plans for specific contamination problems; operational decisions on industrial, wastewater, or water-supply facilities; and research on factors that affect water quality. An additional need for water-quality information is to provide a basis on which regional- and national-level policy decisions can be based. Wise decisions must be based on sound information. As a society we need to know whether certain types of water-quality problems are isolated or ubiquitous, whether there are significant differences in conditions among regions, whether the conditions are changing over time, and why these conditions change from place to place and over time. The information can be used to help determine the efficacy of existing water-quality policies and to help analysts determine the need for and likely consequences of new policies.

To address these needs, the U.S. Congress appropriated funds in 1986 for the USGS to begin a pilot program in seven project areas to develop and refine the National Water-Quality Assessment (NAWQA) Program. In 1991, the USGS began full implementation of the program. The NAWQA Program builds upon an existing base of water-quality studies of the USGS, as well as those of other Federal, State, and local agencies. The objectives of the NAWQA Program are to:

- Describe current water-quality conditions for a large part of the Nation's freshwater streams, rivers, and aquifers.

- Describe how water quality is changing over time.

- Improve understanding of the primary natural and human factors that affect water-quality conditions.

This information will help support the development and evaluation of management, regulatory, and monitoring decisions by other Federal, State, and local agencies to protect, use, and enhance water resources.

The goals of the NAWQA Program are being achieved through ongoing and proposed investigations of 60 of the Nation's most important river basins and aquifer systems, which are referred to as study units. There study units are distributed throughout the Nation and cover a diversity of hydrogeologic settings. More than two-thirds of the Nation's freshwater use occurs within the 60 study units and more than two-thirds of the people served by public water-supply systems live within their boundaries.

National synthesis of data analysis, based on aggregation of comparable information obtained from the study units, is a major component of the program. This effort focuses on selected waterquality topics using nationally consistent information. Comparative studies will explain differences and similarities in observed water-quality conditions among study areas and will identify changes and trends and their causes. The first topics addressed by the national synthesis are pesticides, nutrients, volatile organic compounds, and aquatic biology. Discussions on these and other water-quality topics will be published in periodic summaries of the quality of the Nation's ground and surface water as the information becomes available.

This report is an element of the comprehensive body of information developed as part of the NAWQA Program. The program depends heavily on the advice, cooperation, and information from many Federal, State, interstate, Tribal, and local agencies and the public. The assistance and suggestions of all are greatly appreciated.

Robert M. Hirsch

Chief Hydrologist 


\section{Contents}

Abstract.

Introduction

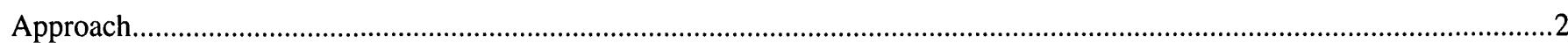

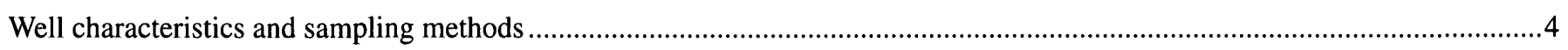

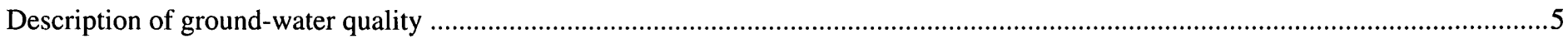

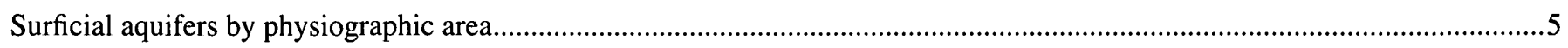

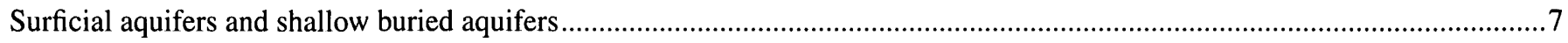

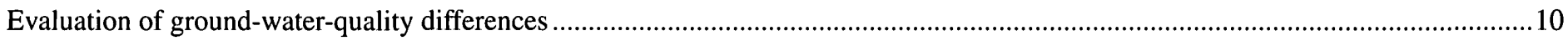

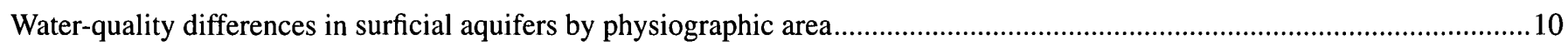

Water-quality differences between surficial and shallow buried aquifers .................................................................11

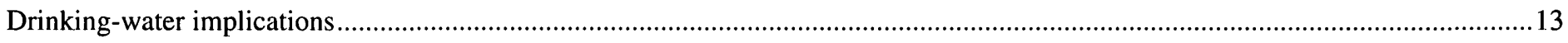

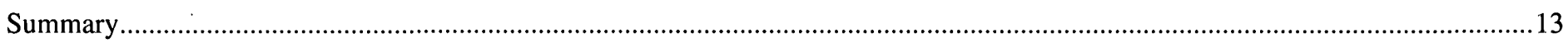

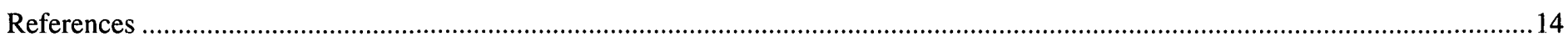

\section{Illustrations}

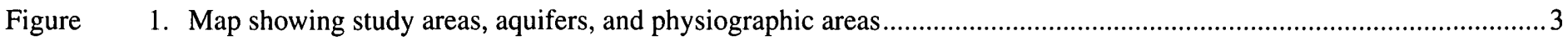

2-3. Boxplots showing:

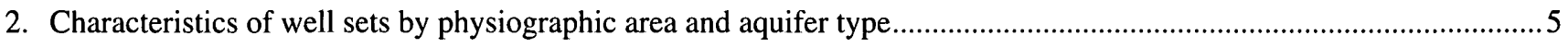

3. Concentration of selected constituents in water in surficial aquifers ..................................................................6

4. Piper diagram showing major-ion composition of waters in surficial aquifers.........................................................

5. Graph showing concentrations of pesticides (and their metabolites) in waters in surficial aquifers ............................ 8

6-7. Boxplots showing:

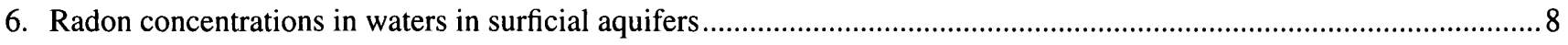

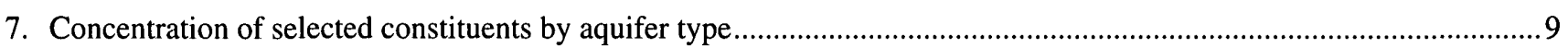

8. Piper diagram showing major-ion composition of waters in shallow buried aquifers ............................................ 10

\section{Tables}

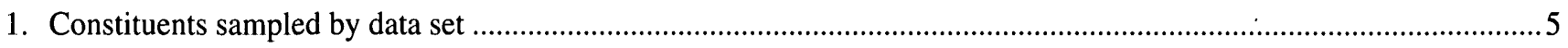

2. Water-quality differences in surficial aquifers between physiographic areas ........................................................6

3. Pesticides (and their metabolites) concentration statistics in waters in surficial aquifers ............................................8

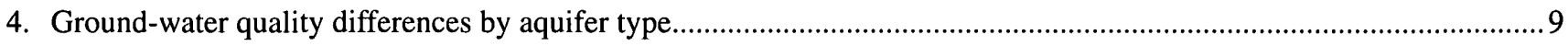

5. U.S. Environmental Protection Agency drinking-water standards and health advisories exceeded in the Red River of the North Basin ground water

\section{Conversion Factors, Abbreviated Water-Quality Units, and Abbreviations}

$\begin{array}{rll}\text { Multiply } & \text { By } & \text { To obtain } \\ \text { foot }(\mathrm{ft}) & 0.3048 & \text { meter } \\ \text { mile } & 1.609 & \text { kilometer } \\ \text { millions of gallons per day }(\mathrm{Mgal} / \mathrm{d}) & 0.0438 & \text { cubic meters per second }\end{array}$

Chemical concentrations: Chemical concentrations of substances in water are given in metric units of milligrams per liter (mg/L) and micrograms per liter $(\mu \mathrm{g} / \mathrm{L})$. These units express the concentration of chemical constituents in solution as mass of solute per unit volume of water.One-thousand micrograms per liter equals one milligrams per liter. 


\title{
Ground-Water Quality in the Red River of the North Basin, Minnesota and North Dakota, 1991-95
}

\author{
By Timothy K. Cowdery
}

\begin{abstract}
Surveys of water quality in surficial, buried glacial, and Cretaceous aquifers in the Red River of the North Basin during 1991-95 showed that some major-ion, nutrient, pesticide, and radioactive-element concentrations differed by physiographic area and differed among these aquifer types. Waters in surficial aquifers in the Drift Prairie (west) and Lake Plain (central) physiographic areas were similar to each other but significantly higher than those in the Moraine (east) area in dissolved solids, sodium, potassium, sulfate, fluoride, silica, and uranium concentrations. Radium, iron, nitrate, and nitrite concentrations were also significantly different among these areas. Pesticides were detected in 12 percent of waters in surficial aquifers in the Drift Prairie area, 20 percent of those in the Lake Plain area, and 52 percent of those in the Moraine area. Triazines and bentazon accounted for 98 percent of summed pesticide concentrations in waters in surficial aquifers. Waters in buried glacial aquifers in the central one-third of the basin had significantly higher concentrations of dissolved solids, sodium, potassium, chloride, fluoride, and iron than did waters in surficial aquifers. No pesticides were detected in five samples from buried glacial aquifers or six samples from Creta-
\end{abstract}

ceous aquifers. Waters in all sampled aquifers had a calciummagnesium ratio of about $1.75 \pm 0.75$ across the basin regardless of anionic composition

Agricultural land use and soil texture can explain pesticide distributions; soil texture best explains nutrient distributions in waters in surficial aquifers. Confining beds protect waters in buried glacial aquifers from land use effects, resulting in no or low concentrations of nutrients and pesticides. Upward movement of bedrock waters high in dissolved solids concentration can increase concentrations in waters in buried glacial and, to a lesser degree, waters in surficial aquifers in the Lake Plain and Drift Prairie areas. Waters in surficial aquifers exceeded the U.S. Environmental Protection Agency (USEPA) maximum contaminant level in drinking water for nitrate in the Drift Prairie (27 percent) and Moraine ( 8 percent) areas. Their limited areal extent and susceptibility to contamination restrict the usefulness of surficial aquifers as a drinking water source. Waters in buried glacial aquifers exceeded USEPA health advisories for dissolved solids, sodium, and manganese. Sixty-six percent of waters in surficial aquifers also exceeded the Health Advisory for manganese. 


\section{Introduction}

Aquifers in glacial sediments and bedrock are important, and in many places, the only source of water for domestic, agricultural and industrial uses in the Red River of the North (hereinafter, Red River) Basin (Stoner and others, 1993). Water in these aquifers is of variable quality, however. Many of the factors that can affect water quality (land use, hydrogeology, and climate) in the Red River Basin vary with physiographic area. Ground-water quality may also vary with physiographic area. Knowledge of how and why ground-water quality varies in the basin is essential to the wise use of that water.

The landscape in the Red River Basin is flat in the center of the basin, and hilly toward its east and west margins. The flat area is dominated by clays of a former large glacial lake (Lake Agassiz), and the hilly areas are composed of glacial tills, stratified ice-contact deposits and outwash plains. Large deltaic deposits lie along the western margin of Lake Agassiz.

Underlying the unconsolidated sediments, consolidated sedimentary bedrock in the Red River Basin is part of the westwarddipping eastern limb of the Williston Basin. This basin is a syncline (roughly north-south axis) that extends from extreme northwestern Minnesota, across the Dakotas and into eastern Wyoming and Montana. These rocks are predominantly sandstones, carbonates, and shales, range in age from Cambrian to Tertiary, and reach depths of nearly 5,000 feet at the western edge of the Red River Basin (Stoner and others, 1993). Where this sedimentary bedrock is absent, glacial deposits are underlain by nearly impermeable crystalline bedrock.

Aquifers in the basin occur in either unconsolidated sediments or consolidated bedrock. The former are composed of materials ranging in grain size from silt and fine sand to coarse pebbles. Stratified, glacially-deposited (hereinafter, glacial) sediment and alluvium commonly form these aquifers, referred to as glacial aquifers in this report. Aquifers occurring in bedrock are called bedrock aquifers in this report.

Aquifers are classified as either surficial or buried in this report. Surficial aquifers are exposed at the land surface. Buried aquifers are overlain by a confining bed of low permeability till or clay that is a barrier to water flow. In this report, aquifers in the Red River Basin are grouped into three types: surficial aquifers, shallow buried aquifers, and deep bedrock aquifers. Surficial aquifers include only glacial aquifers because no bedrock aquifer is surficial in the basin. Shallow buried aquifers are considered to include buried glacial aquifers and Cretaceous-age bedrock aquifers because these were the only buried aquifers sampled in this study. Deep bedrock aquifers refer to those in pre-Cretaceousage sedimentary bedrock.

The areal extent of major surficial and bedrock aquifersis shown in figure 1. The extent of buried glacial aquifers is less well known. Stoner and others (1993) categorized buried glacial aquifers into three types: bedrock valley-fill, buried outwash plains, and buried channels. These aquifers range in size from one-half to more than 200 miles long, one-quarter to 20 miles wide and 10 to 550 feet thick. Buried glacial aquifers tend to be larger and more continuous in the western and southern parts of the basin. Many small, thin, and discontinuous buried glacial aquifers remain unmapped throughout the basin, judging from records of sand and gravel reported in water-well logs.

Water in surficial aquifers is of good quality, but is susceptible to contamination from land uses (Cowdery, 1997). The generally good-quality water in shallow buried aquifers can be affected by upward movement of water containing high concentrations of dissolved-solids from deep bedrock aquifers of the Williston Basin (Downey, 1986; fig. 1).

In 1991, the U.S. Geological Survey (USGS) began a study of the water resources of the Red River Basin within the United States (the study unit, fig. 1) through its National Water Quality Assessment (NAWQA) Program. This basin was selected among the first 20 NAWQA study units because its water is a valuable regional resource, its water flows across an international boundary into Canada, its land is used heavily for agriculture, and its northern location enables a more complete understanding of the Nation's water quality. A broad sampling of existing wells across the basin, called a study-unit survey (Gilliom and others, 1995), was designed to characterize the general ground-water quality of the basin.

This report presents the results of the Red River Basin NAWQA study-unit survey. The specific purposes of this report are: 1) to describe the water quality in surficial aquifers (in three physiographic areas) and in shallow buried aquifers; 2) to contrast and explain the water-quality differences among surficial aquifers (in each physiographic area) and between surficial and shallow buried aquifers; and 3) to describe the implications of ground-water quality on drinking water in the Red River Basin.

\section{Approach}

Lorenz and Stoner (1996) identified four major physiographic areas within the Red River Basin that are fairly homogeneous in terms of factors affecting water quality (fig. 1). These areas are primarily geomorphically distinct, but also differ in climate, geology, hydrology, soils, land use, and biology. Although physiography does not affect water quality in itself, the other characteristics that differ with physiographic area do affect it. In this report, the term physiographic area implies the climate, geology, hydrology, soils, land use, and biology in each physiographic area. Three physiographic areas (Drift Prairie, Red River Valley Lake Plain (hereinafter, Lake Plain), and Moraine, from west to east, fig. 1) contain substantial numbers of surficial aquifers. Water quality in surficial aquifers in these physiographic areas is the main focus of this study because they are most susceptible to water-quality changes from human activities. The part of each physiographic area containing surficial aquifers was divided into at least 25 equal-area polygons and a sampling location was chosen at a randomly selected point in each polygon (Scott, 1990). The available observation well or domestic well nearest to this point was sampled once during 1993-95 (see Lapham and others, 1995, for well selection criteria) with the following exception: an earlier study conducted during 1991-92 in 


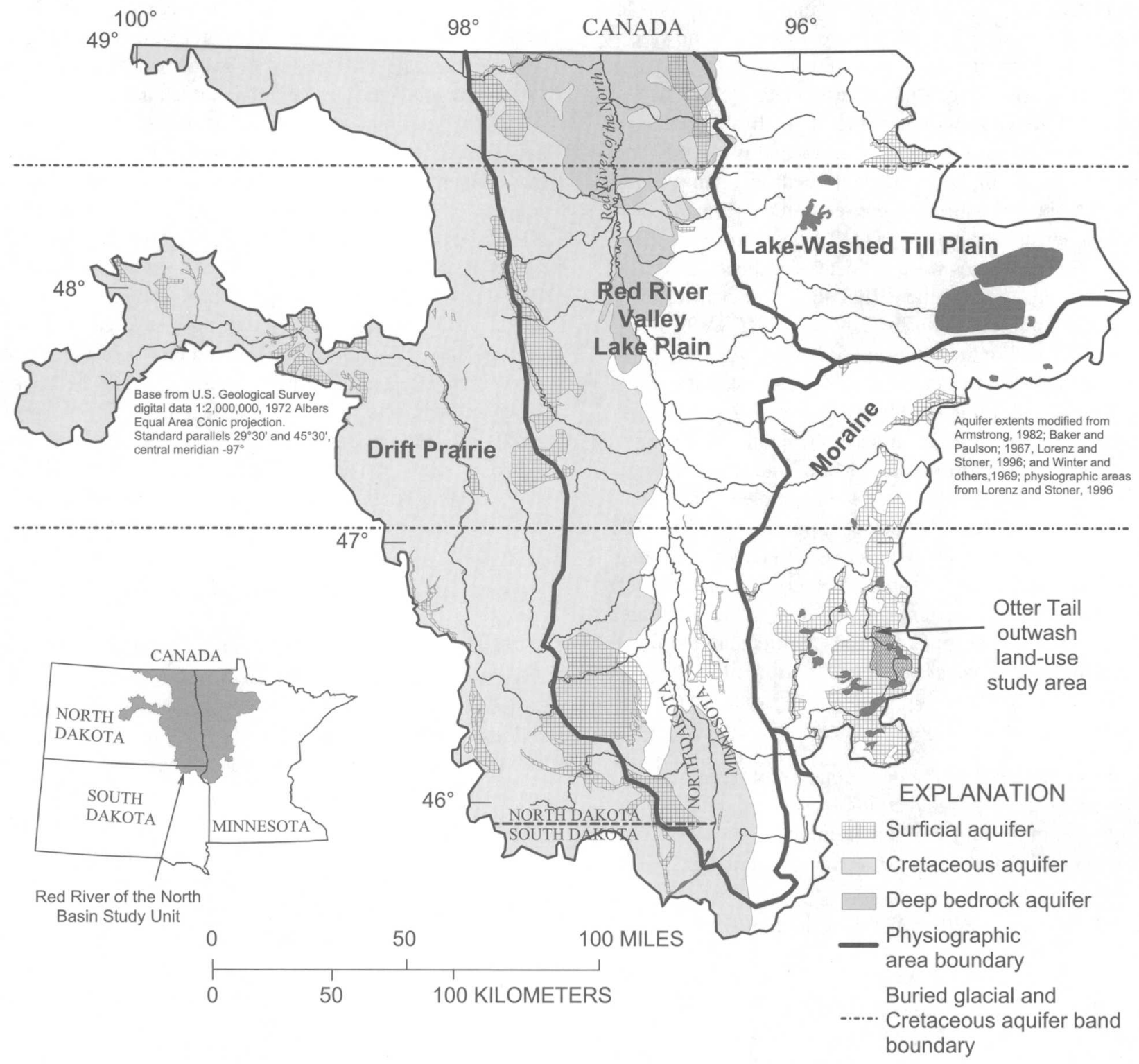

Figure 1. Study areas, aquifers, and physiographic areas.

northwestern Minnesota (Lindgren, 1996) used the same sampling methods as did this study. If the location of a sample from this earlier study fell near a randomly selected point, results from this earlier study were used and the well was not resampled. The water quality of samples from wells chosen in this way form a statistically valid characterization of the water quality in surficial aquifers for each physiographic area.

The boundary between the Lake Plain and the Drift Prairie areas bisects several large surficial aquifers (fig. 1). It was considered best not to subdivide aquifers for the purposes of waterquality evaluation. Therefore, these aquifers were assigned to the Lake Plain physiographic area because their water quality was more similar to that of other aquifers in that area.

This selection process produced sets of samples from surficial aquifers in each physiographic area: Drift Prairie (15 samples),
Lake Plain (29 samples), and Moraine (25 samples). Taken together, these 69 samples characterized water quality in surficial aquifers generally. Three of the 29 Lake Plain area samples were collected for the earlier study in northwestern Minnesota (Lindgren, 1996). Fewer wells were sampled in the Drift Prairie area because aquifers along the eastern boundary were assigned to the Lake Plain area, reducing the number of wells remaining in the Drift Prairie area. Additional wells were not sampled in this area because it contains so few surficial aquifers that appropriate wells could not be found. Therefore, water-quality statistics in the Drift Prairie area have greater uncertainties.

In addition to the samples which characterized surficial aquifers, samples were collected from 33 wells in buried glacial aquifers and 9 wells in Cretaceous aquifers within a 90-mile-wide east-west band across the central part of the basin (fig. 1). When considered together, these 42 samples characterized water quality 
in shallow buried aquifers. Water quality in these aquifers is less affected by land use from above but more affected by upward movement of highly mineralized ground water from deep bedrock aquifers than is water quality in surficial aquifers. The band which contained these wells crosses the three physiographic areas sampled for water in surficial aquifers and is roughly parallel to the westward dip of the sedimentary bedrock. Samples from wells in shallow buried aquifers were restricted to this band to achieve a data density equivalent to the surficial aquifer waterquality data. These samples were collected for this study during 1993-95 at 27 wells, and for the earlier study in northwestern Minnesota (Lindgren, 1996) during 1991-92 at 15 wells. Locations of the wells within the 90-mile-wide band were selected with the same method used to select wells in surficial aquifers with the following additional criteria: 1) all wells had to be screened in aquifers overlain by at least one confining bed and 2) if wells sampled for the northwestern Minnesota study lay within an equal-area polygon, data from the well sampled in that study that was closest to the randomly-selected point were used. The 33 samples from buried glacial aquifers characterize water quality in these aquifers within the sampled band, but may not represent water quality in all buried glacial aquifers in the study area. Although the 9 samples from Cretaceous aquifers are too few to statistically characterize water quality in these aquifers, they give an indication of the quality of upward-moving water that may affect water quality in buried glacial aquifers.

These data sets facilitate the interpretation of effects of differences in physiographic area and aquifer type on water quality. Accordingly, the implications of water quality on drinking water throughout the Red River Basin can be better evaluated.

\section{Well Characteristics and Sampling Methods}

Characteristics of sampled wells in surficial aquifers were generally similar to each other regardless of physiographic area but different from those of sampled wells in shallow buried aquifers (fig. 2). The median well depth and the depth of the midpoint of the well screen below the water table (hereinafter, screen depth) are 2.7 times and 4.0 times greater in sampled wells in buried glacial aquifers. These medians increased for sampled wells in surficial aquifers from west to east (fig. 2). Median screen lengths were 4 to $5.5 \mathrm{ft}$ for all sets of sampled wells except the Cretaceous aquifer set, for which it was $10 \mathrm{ft}$. Some characteristics of some wells were not known. The type of aquifer for one well in Minnesota was not known. It was assumed to be in a buried glacial aquifer because wells completed in Cretaceous aquifers in northwestern Minnesota are unusual. Most wells sampled were used as observation wells (48 percent) or for domestic supply (44 percent). Most wells (62 percent) in the surficial aquifer well set were observation wells and most (62 percent) in the shallow buried aquifer well set were domestic supply wells.

Sampling methods used in this study (Koterba and others, 1995) stress sampling contamination prevention and groundwater-constituent preservation. Menheer and Brigham (1997) detailed slight deviations from these methods that were employed in this study. They also reviewed the quality-control data collected, showing that samples accurately characterized the ground water. Table 1 lists the groups of water-quality constituents measured for each data set. Specific conductance, temperature, dissolved oxygen concentration, and alkalinity were measured in the field for each sample. Major-ion, nutrient, pesticide, and radioactive-element concentrations measured in samples from surficial aquifers characterized natural water quality, indicated land-use effects, or both. Samples were analyzed for 86 pesticides and metabolites, some of which were not used in the study area. See Cowdery (1997) for a list of pesticides analyzed. Thirteen majorion and 15 trace-metal concentrations measured in samples from shallow buried aquifers characterized natural water quality and showed the effects of upward movement of deep bedrock water to these aquifers. The statistical significance of differences in waterquality constituents among these data sets was quantified with the Wilcoxon rank-sum test and reported as significant if there is less than a 5 percent chance that the differences could be due to random sampling of the same population.

\section{Description of Ground-Water Quality}

Waters in surficial aquifers in the Red River Basin are of the calcium-magnesium bicarbonate type. Water types in shallow buried aquifers range from calcium-magnesium bicarbonate to sodium chloride. In general, waters in surficial aquifers had higher concentrations of nutrients and pesticides than did waters from shallow buried aquifers. Waters in surficial aquifers generally had the lowest concentrations of major ions, radioactive elements, and trace metals, whereas waters from Cretaceous aquifers had the highest concentrations of these constituents. Waters from buried glacial aquifers were intermediate in composition between those in surficial aquifers and those in Cretaceous aquifers. This gradational change in water quality is consistent with the proximity of these aquifers to the sources of these dissolved substances. For example, nutrients and pesticides originate at the land surface and are dissolved by the infiltrating waters that recharge surficial aquifers. Therefore, the highest concentrations of these chemicals were near land surface in surficial aquifers. Major ions, radioactive elements, and trace metals dissolve naturally in ground waters from contact with aquifer materials. The longer ground water is in contact with the aquifer, the higher these concentrations tend to be. Deeper ground waters are generally older and have had more time to dissolve elements from the aquifer material. Therefore, the highest concentrations of these chemicals were in Cretaceous aquifers, the deepest sampled. Waters from both surficial and Cretaceous aquifers can affect water quality in buried glacial aquifers where overlain or underlain by them.

\section{Surficial Aquifers by Physiographic Area}

Waters in surficial aquifers in the Red River Basin were fairly low in dissolved-solids concentration and of good drinking-water quality. Median specific conductance was 651 microsiemens per centimeter $(\mu \mathrm{S} / \mathrm{cm})$ and median dissolved solids concentration was $400 \mathrm{mg} / \mathrm{L}$. Water quality in surficial aquifers differed with 


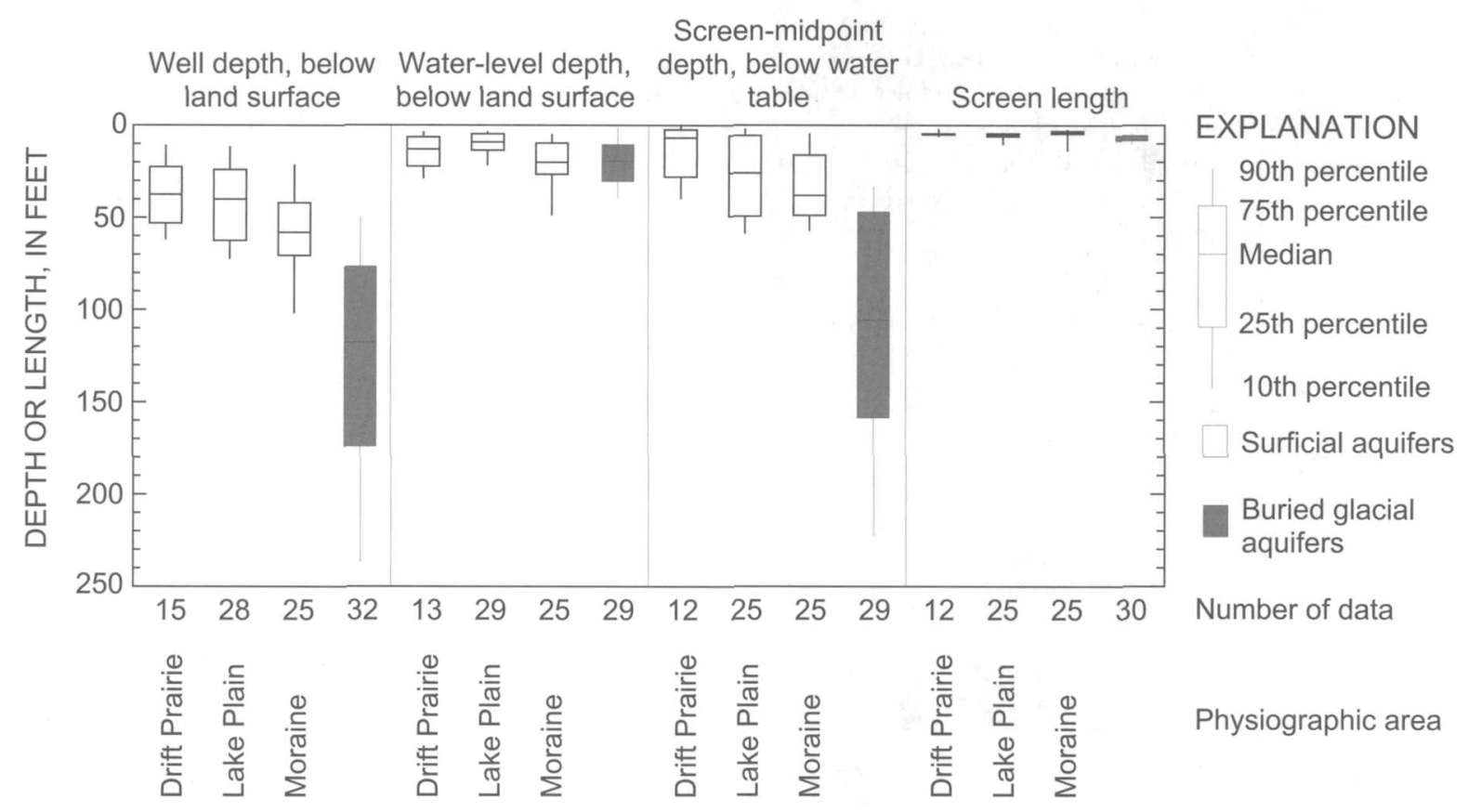

Figure 2. Characteristics of well sets by physiographic area and aquifer type.

Table 1. Constituents sampled by data set

[NWGW, northwestern Minnesota (Lindgren, 1996) ground water; GCMS, gas chromatography/mass spectroscopy; HPLC, high performance liquid chromatography; VOCs, volatile organic compounds; shaded areas: too few samples to form statistically significant or accurate data sets, but provide an indication of water quality]

\begin{tabular}{|c|c|c|c|c|c|c|c|c|c|c|}
\hline \multirow[b]{2}{*}{ Data set } & \multirow[b]{2}{*}{$\begin{array}{l}\text { Total } \\
\text { wells }\end{array}$} & \multirow[b]{2}{*}{$\begin{array}{l}\text { NWGW } \\
\text { study wells }\end{array}$} & \multirow[b]{2}{*}{$\begin{array}{l}\text { Major } \\
\text { ions }\end{array}$} & \multirow[b]{2}{*}{$\begin{array}{l}\text { Nutri- } \\
\text { ents }\end{array}$} & \multicolumn{2}{|c|}{ Pesticides } & \multirow[b]{2}{*}{ VOCs } & \multicolumn{2}{|c|}{ Radioactive elements } & \multirow[b]{2}{*}{$\begin{array}{l}\text { Trace } \\
\text { metals }\end{array}$} \\
\hline & & & & & $\begin{array}{c}\text { GCM } \\
\mathrm{S}\end{array}$ & HPLC & & $\begin{array}{l}\text { Uranium } \\
\text { and radium }\end{array}$ & Radon & \\
\hline Drift Prairie & 15 & 0 & 15 & 15 & 15 & 15 & 1 & 15 & 5 & 0 \\
\hline Lake Plain & 29 & 3 & 27 & 28 & 26 & 26 & 8 & 26 & 14 & 4 \\
\hline Moraine & 25 & 0 & 24 & 25 & 25 & 25 & 10 & 25 & 22 & 10 \\
\hline Buried glacial & 33 & 15 & 33 & 10 & 5 & 5 & 0 & 18 & 8 & 33 \\
\hline Cretaceous & 9 & 0 & 9 & 6 & 6 & 6 & 0 & 8 & 5 & 9 \\
\hline \multicolumn{3}{|c|}{ Laboratory analytical method number } & 2750 & 2752 & 2001 & 2050 & 2090 & 1810 & 1369 & 2703 \\
\hline & erence & & $\begin{array}{l}\text { Fish- } \\
\text { man, } \\
1993\end{array}$ & $\begin{array}{l}\text { Fish- } \\
\text { man, } \\
1993\end{array}$ & $\begin{array}{l}\text { Zaugg } \\
\text { and } \\
\text { oth- } \\
\text { ers, } \\
1995\end{array}$ & $\begin{array}{l}\text { Werner } \\
\text { and } \\
\text { others, } \\
1996\end{array}$ & $\begin{array}{l}\text { Rose } \\
\text { and } \\
\text { Schroe } \\
\text {-der, } \\
1995\end{array}$ & \multicolumn{2}{|c|}{$\begin{array}{c}\text { U.S. Environmental Pro- } \\
\text { tection Agency, 1980; } \\
\text { American Society for } \\
\text { Testing and Materials, } \\
\text { 1996a, 1996b }\end{array}$} & $\begin{array}{c}\text { Faires, } \\
1993\end{array}$ \\
\hline
\end{tabular}

physiographic area. Constituents other than pesticides that had statistically different concentrations in surficial aquifers between physiographic areas are listed in Table 2. Figure 3 is a graphical comparison of the concentration of some of these constituents. In general, waters in surficial aquifers in the Drift Prairie and Lake Plain areas were similar to each other and different from waters in surficial aquifers in the Moraine area. Among the constituents for which this pattern holds (residue on evaporation and dissolved solids (considered together), sodium, potassium, sulfate, silica, uranium, and radium; table 2), concentrations were higher in waters from the Drift Prairie and Lake Plain surficial aquifers than in those from the Moraine area, excepting radium.
For iron, nitrate plus nitrite as nitrogen $(\mathrm{N})$ (hereinafter, nitrate), and nitrite as $\mathrm{N}$ (hereinafter, nitrite), surficial aquifers with similar concentrations grouped differently. Iron concentrations were higher in waters from Lake Plain and Moraine surficial aquifers than in those from the Drift Prairie area. Nitrate and nitrite concentrations were higher in waters from the Drift Prairie and Moraine surficial aquifers than in those from the Lake Plain area. Many constituents were not significantly different among the three physiographic areas, however. Differences in major-ion composition between waters from Drift Prairie and Lake Plain surficial aquifers and Moraine surficial aquifers are shown in figure 4. Most waters in Moraine surficial aquifers group tightly in 
Table 2. Water-quality differences in surficial aquifers between physiographic areas

$[\mathrm{H}$, constituent higher in first physiographic area than in second; $\mathrm{L}$, constituent lower in first physiographic area than in second; - , no statistically significant differences; $\mathrm{N}$, nitrogen; $\mathrm{P}$, phosphorus; < less than]

\begin{tabular}{|c|c|c|c|c|c|c|}
\hline \multirow{2}{*}{ Constituent } & \multicolumn{3}{|c|}{$\begin{array}{c}\text { Significant differences }{ }^{\mathrm{a}} \text { between physiographic } \\
\text { area pairs }\end{array}$} & \multicolumn{3}{|c|}{ Physiographic area median concentration or value } \\
\hline & $\begin{array}{l}\text { Drift Prairie- } \\
\text { Lake plain }\end{array}$ & $\begin{array}{l}\text { Moraine- } \\
\text { Drift prairie }\end{array}$ & $\begin{array}{l}\text { Moraine- } \\
\text { Lake plain }\end{array}$ & Drift prairie & Lake plain & Moraine \\
\hline Dissolved oxygen & $\mathrm{H}$ & - & - & $<0.1$ & $<0.1$ & $<0.1$ \\
\hline Specific conductance & $\mathrm{H}$ & - & - & 661.5 & 703.5 & 616 \\
\hline Residue on evaporation & - & $\mathrm{L}$ & - & 445 & 465 & 334 \\
\hline Dissolved solids & - & - & $\mathrm{L}$ & 437 & 459 & 360 \\
\hline Sodium & - & $\mathrm{L}$ & $\mathrm{L}$ & 6.4 & 8.9 & 2.8 \\
\hline Potassium & - & $\mathrm{L}$ & $\mathrm{L}$ & 3.2 & 3.7 & 2.1 \\
\hline Sulfate & - & $\mathrm{L}$ & $\mathrm{L}$ & 61 & 76 & 11 \\
\hline Fluoride & - & - & $\mathrm{L}$ & 0.2 & 0.2 & 0.15 \\
\hline Iron & $\mathrm{L}$ & $\mathrm{H}$ & - & 0.015 & 0.34 & 1.7 \\
\hline Silica & - & $\mathrm{L}$ & $\mathrm{L}$ & 26 & 28 & 24 \\
\hline Nitrate plus nitrite (as N) & $\mathrm{H}$ & - & $\mathrm{H}$ & 0.39 & $<0.05$ & $<0.05$ \\
\hline Nitrite (as N) & $\mathrm{H}$ & - & $\mathrm{H}$ & $<0.01$ & $<0.01$ & $<0.01$ \\
\hline Ammonia (as N) & $\mathrm{L}$ & - & - & 0.03 & 0.165 & 0.1 \\
\hline Phosphorus (ortho, as P) & - & - & $\mathrm{H}$ & 0.03 & 0.01 & 0.02 \\
\hline Uranium & - & $\mathrm{L}$ & $\mathrm{L}$ & 0.002 & 0.0013 & 0.0004 \\
\hline Radium & - & $\mathrm{H}$ & $\mathrm{H}$ & 0.1 & 0.2 & 0.3 \\
\hline
\end{tabular}

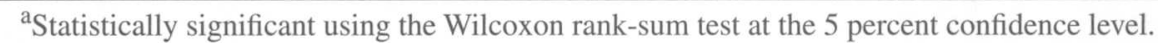

${ }^{b}$ Measured in milligrams per liter except for specific conductance, which is measured in microsiemens per centimeter, and for radium, which is measured in picocuries per liter.

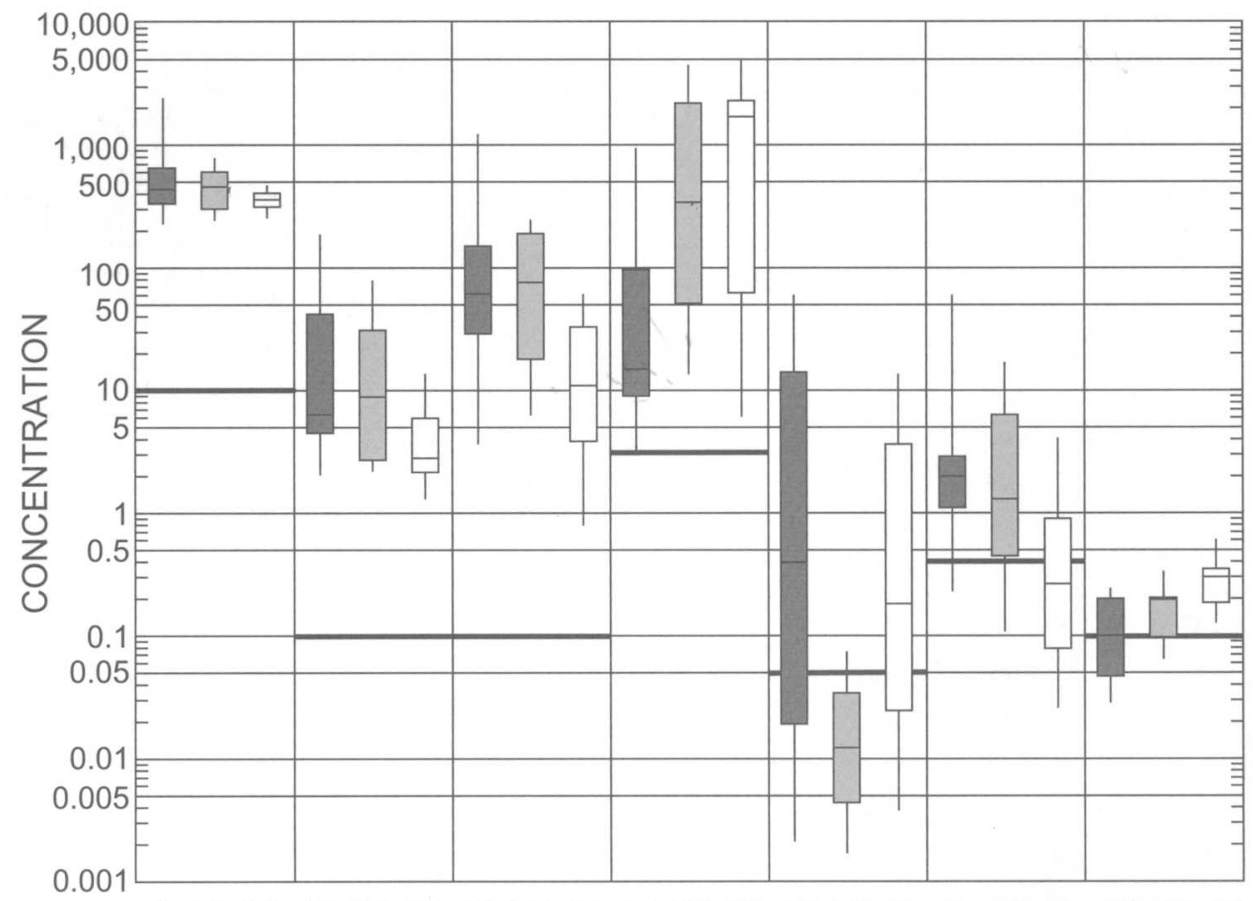

152623152725152724152725152625152625152625

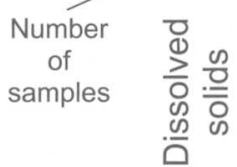

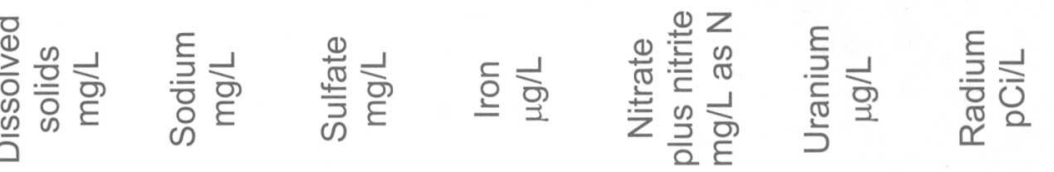

\section{EXPLANATION}

90th percentile

75th percentile

Median

25th percentile

10th percentile

Physiographic area

Drift Prairie

Lake Plain

Moraine

Reporting limit

Percentiles below the reporting limit are extrapolated using probability-plot regression (Helsel and Hirsch, 1992); (mg/L, milligrams per liter; $\mu \mathrm{g} / \mathrm{L}$, micrograms per liter; $\mathrm{N}$, nitrogen, $\mathrm{pCi} / \mathrm{L}$, picocuries per liter)

Figure 3. Concentration of selected constituents in water in surficial aquifers. 
the left corner of the upper diamond, indicating dominance by calcium, magnesium, and bicarbonate ions. Although the concentrations of these ions were not statistically different from Moraine waters, Drift Prairie and Lake Plain waters are more spread toward the upper corner of the diamond, showing a somewhat higher concentration of sulfate ions in these waters.

Pesticides and their metabolites (hereinafter, pesticides) in waters in surficial aquifers also differed according to physiographic area. Moraine surficial aquifers were much more likely to contain pesticides ( 52 percent of waters) and contained more kinds of pesticides (7) than other surficial aquifers (table 3, fig. 5 ). Five of the 7 pesticides detected in samples for this study were herbicides. In surficial aquifers, 99.4 percent of summed pesticide concentrations are herbicides. The principal herbicides detected in the moraine and Lake Plain areas were triazines, (atrazine and simazine) and the atrazine metabolite deethylatrazine; these three together formed about 90 percent of summed pesticide concentration. Bentazon was the main herbicide detected in the Drift Prairie area (94 percent of summed pesticide concentration). If an herbicide was detected, the concentration was generally relatively high in the Lake Plain area and relatively low in the Moraine area. Triazines and bentazon accounted for 4 of 7 detected pesticides, and 98 percent of summed pesticide con- centration in all waters from surficial aquifers in the Red River Basin. The DDT metabolite $p, p$ '-DDE was found in 4 percent of waters from the Lake Plain area and 16 percent of waters from the Moraine area; all concentrations were very low $(0.002 \mu \mathrm{g} / \mathrm{L})$.

Radon concentrations in waters from the Lake Plain and Moraine surficial aquifers are shown in figure 6. Only 14 of the 29 samples from the Lake Plain area were analyzed for radon and, therefore, do not constitute a statistically comparable sample set. Radon concentration's were similar in the other two physiographic areas.

\section{Surficial Aquifers and Shallow Buried Aquifers}

Waters in buried glacial and Cretaceous aquifers had significantly higher dissolved-solids concentrations than did waters in surficial aquifers as a whole. Median specific conductance and dissolved solids were $855 \mu \mathrm{S} / \mathrm{cm}$ and $523 \mathrm{mg} / \mathrm{L}$, respectively, for waters in the buried glacial aquifers and 3,180 $\mu \mathrm{S} / \mathrm{cm}$ and 1,790 $\mathrm{mg} / \mathrm{L}$, respectively, for samples from Cretaceous aquifers (table 4, fig. 7). (The characterization of water quality in Cretaceous aquifers presented below is not statistically valid for the Cretaceous aquifers in the Red River of the North Basin as a whole. The characterization does give an indication of the quality of ground water that underlies and, in some places, moves upward

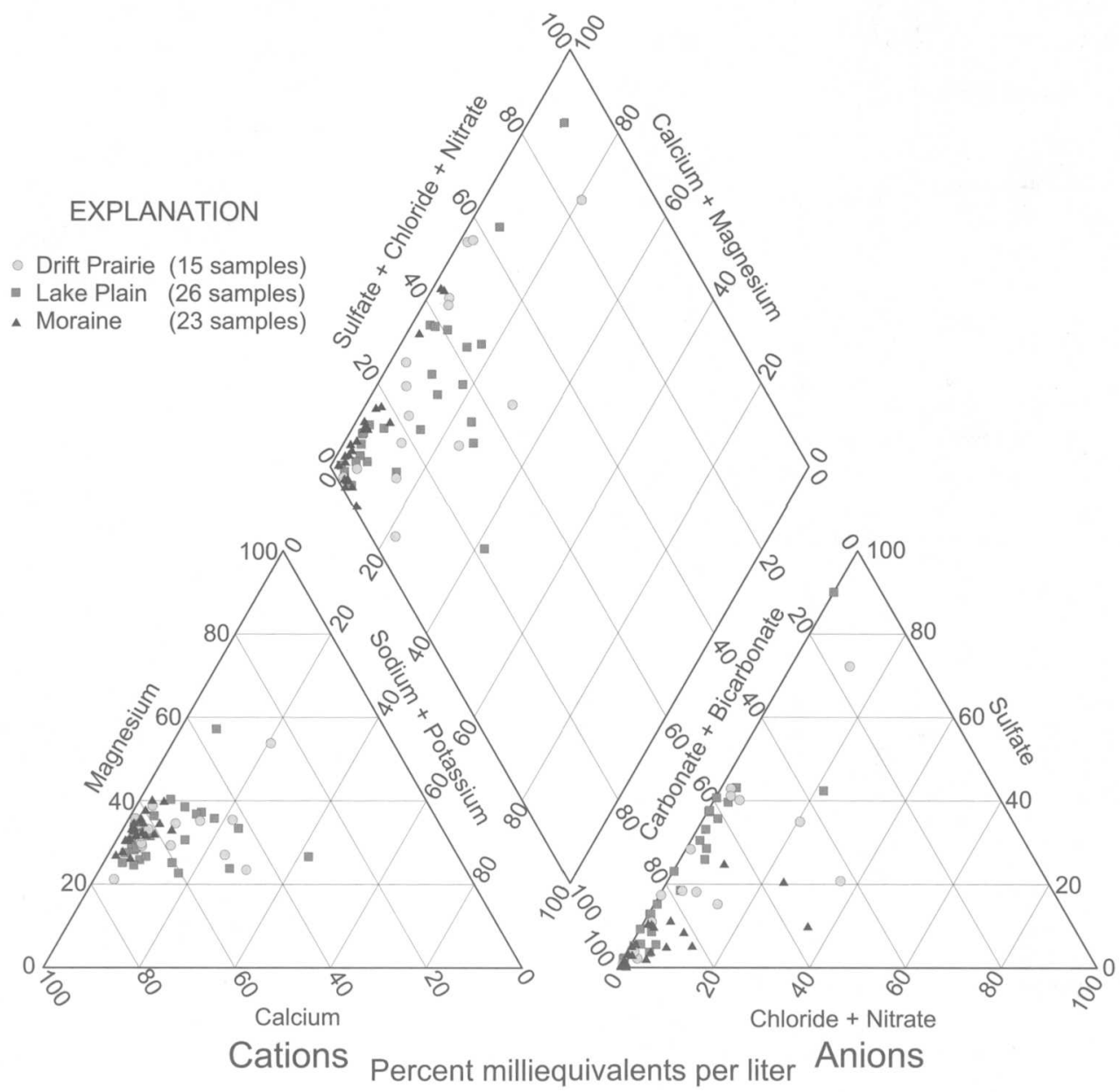

Figure 4. Major-ion composition of waters in surficial aquifers. 
Table 3. Pesticide (and their metabolites) concentration statistics in waters in surficial aquifers

[concentrations in micrograms per liter]

\begin{tabular}{|c|c|c|c|}
\hline & \multicolumn{3}{|c|}{ Physiographic area } \\
\hline & \begin{tabular}{|c} 
Drift \\
Prairie
\end{tabular} & $\begin{array}{l}\text { Lake } \\
\text { Plain }\end{array}$ & Moraine \\
\hline Number of pesticide detected & 3 & 5 & 7 \\
\hline Wells with pesticides/wells sampled & $3 / 15$ & $3 / 26$ & $13 / 25$ \\
\hline $\begin{array}{l}\text { Average summed pesticide concentra- } \\
\text { tion }\end{array}$ & 0.013 & 0.047 & 0.029 \\
\hline $\begin{array}{l}\text { Median summed pesticide concentration } \\
\text { of samples containing pesticides }\end{array}$ & 0.05 & 0.12 & 0.007 \\
\hline Wells with triazines & 1 & 1 & 9 \\
\hline Average summed triazine concentration & 0.001 & 0.042 & 0.026 \\
\hline $\begin{array}{l}\text { Percentage of summed pesticide concen- } \\
\text { tration that is triazines }\end{array}$ & 6 & 89 & 90 \\
\hline $\begin{array}{l}\text { Median summed triazine concentration } \\
\text { of samples containing triazines }\end{array}$ & 0.011 & 1.09 & 0.008 \\
\hline Wells with bentazon & 2 & 1 & 1 \\
\hline Average bentazon concentration & 0.012 & 0.005 & 0.002 \\
\hline $\begin{array}{l}\text { Percentage of summed pesticide concen- } \\
\text { tration that is bentazon }\end{array}$ & 94 & 10 & 6 \\
\hline $\begin{array}{l}\text { Median bentazon concentration of sam- } \\
\text { ples containing bentazon }\end{array}$ & 0.09 & 0.12 & 0.04 \\
\hline
\end{tabular}

to buried glacial and surficial aquifers, however.) Waters in buried glacial aquifers had significantly higher concentrations of six major ions compared to waters in surficial aquifers (table 4, fig. 7). Some samples were not analyzed for some constituents in surficial and buried glacial aquifer groups (shaded boxes, table 4). Although the fewer data available for dissolved oxygen, bromide and ammonia in waters from surficial and buried glacial aquifers preclude statistical analysis of these constituents, the median concentration of dissolved oxygen was lower, and bromide and ammonia higher, in samples from buried glacial aquifers than in samples from surficial aquifers. While not significantly different between waters in surficial and buried glacial aquifers, median concentration of sulfate was higher, and of radon lower, in buried glacial aquifers. Several major ions and nutrients, including calcium, magnesium, silica, manganese, nitrate, and nitrite, had no significant difference between waters in surficial and buried glacial aquifers.

Samples from Cretaceous aquifers had significantly higher concentrations than did waters from surficial and buried glacial aquifers for most constituents. Median sodium and chloride concentrations were more than 100 times higher than in waters in surficial aquifers and median sulfate concentration was more than 20 times higher than in waters in surficial aquifers (table 4, fig. 7). Figure 8 shows the relation between the major-ion composition of waters in shallow buried aquifers. Waters in buried glacial aquifers did not group closely in the diamond, showing no dominant ionic composition. Distribution in the cation triangle (lower left) shows both ground waters grouped, however. Sodium concentration varied greatly (range: $2.2-3,400 \mathrm{mg} / \mathrm{L}$ ) in waters in shallow buried aquifers, but maintained a relatively constant calcium-magnesium ratio of about $1.75 \pm 0.75$.

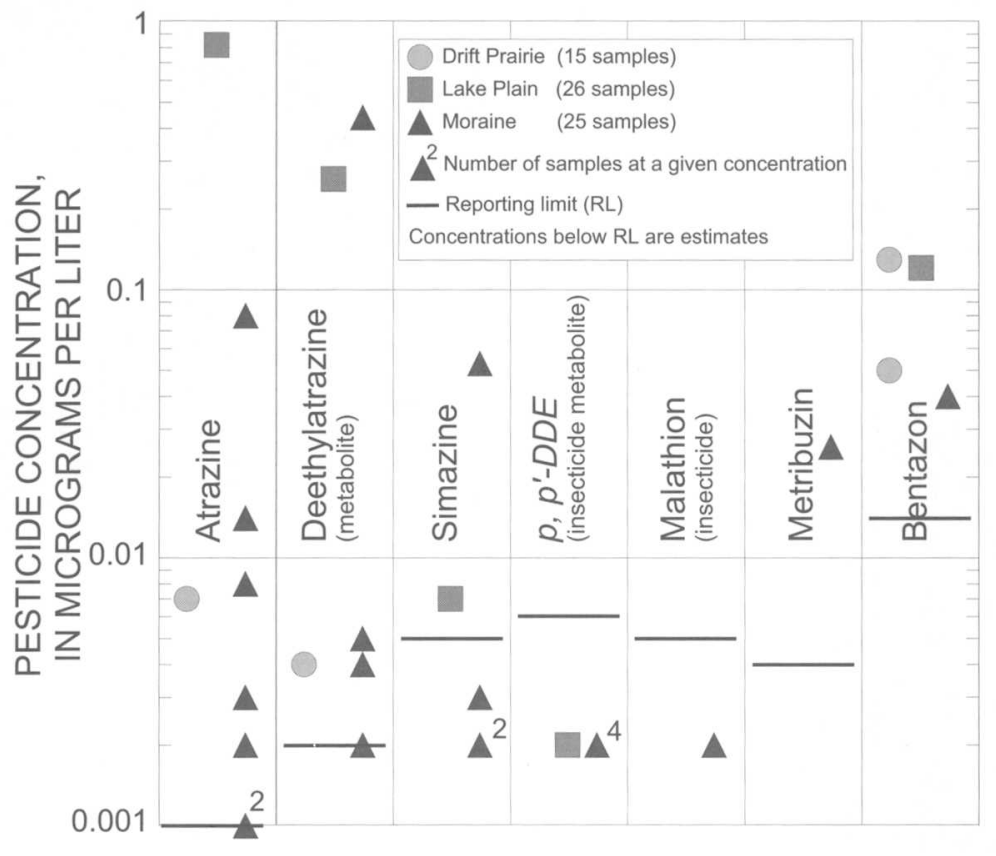

Figure 5. Concentrations of pesticides (and their metabolites) in waters in surficial aquifers.

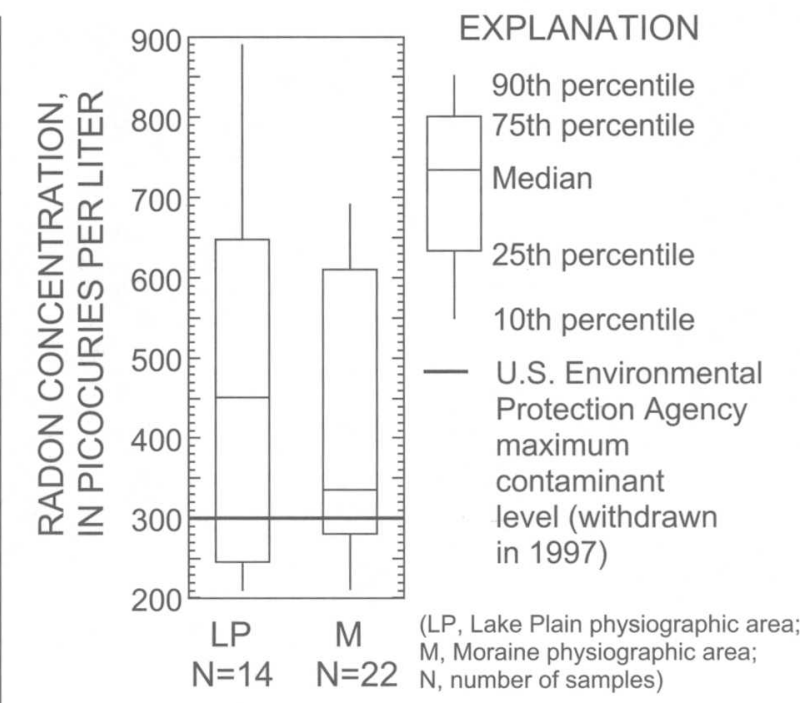

Figure 6. Radon concentrations in waters in surficial aquifers. 
Table 4. Ground-water quality differences by aquifer type

[S, surficial aquifers; BG, buried glacial aquifers; $\mathrm{C}$, Cretaceous aquifers; $\mathrm{H}$, constituent higher in buried glacial aquifers; L, constituent lower in buried glacial aquifers; <, less than; /, divided by; $N$, nitrogen; - no statistically significant difference; shaded box: too few samples to accurately characterize aquifers, but sample sets are significantly different]

\begin{tabular}{l|c|ccccc}
\hline & $\begin{array}{c}\text { Significant } \\
\text { difference }\end{array}$ & \multicolumn{5}{c}{ Median $^{\mathrm{b}}$} \\
\cline { 3 - 7 } & BG vs. S & $\mathrm{S}$ & $\mathrm{BG}$ & $\mathrm{C}^{\mathrm{c}}$ & $\mathrm{BG} / \mathrm{S}$ & $\mathrm{C} / \mathrm{S}$ \\
\hline Specific conductance & $\mathrm{H}$ & 651 & 855 & 3180 & 1.31 & 4.88 \\
Dissolved oxygen & $\mathrm{L}$ & $<0.1$ & $<0.1$ & 0.1 & 1 & 1 \\
Residue on evaporation & $\mathrm{H}$ & 372 & 504 & 1890 & 1.35 & 5.08 \\
\hline Dissolved solids & $\mathrm{H}$ & 400 & 523 & 1790 & 1.31 & 4.48 \\
Sodium & $\mathrm{H}$ & 6 & 73 & 630 & 12.17 & 105 \\
Potassium & $\mathrm{H}$ & 3 & 5.5 & 11 & 1.83 & 3.67 \\
Bicarbonate & $\mathrm{H}$ & 339 & 376 & 526 & 1.11 & 1.55 \\
Chloride & $\mathrm{H}$ & 3.45 & 14 & 440 & 4.06 & 127.54 \\
Sulfate & - & 34 & 70 & 720 & 2.06 & 21.18 \\
Fluoride & $\mathrm{H}$ & 0.2 & 0.3 & 0.8 & 1.5 & 4 \\
Iron & $\mathrm{H}$ & 0.25 & 1.1 & 1.2 & 4.4 & 4.8 \\
Bromide & $\mathrm{H}$ & 0.04 & 0.125 & 0.37 & 3.13 & 9.25 \\
Ammonia (as N) & $\mathrm{H}$ & 0.085 & 0.77 & 2.5 & 9.06 & 29.41 \\
Ammonia plus organic N & $\mathrm{H}$ & 0.3 & 0.85 & 2.7 & 2.83 \\
(as N) & & & & & 9 \\
\hline
\end{tabular}

${ }^{\text {a }}$ Statistically significant using the Wilcoxon rank-sum test at the 5 percent confidence level

${ }^{b}$ Medians are not statistically valid for Cretaceous aquifers in the Red River of the North Basin

${ }^{\mathrm{c}}$ Measured in milligrams per liter except specific conductance, which is measured in microsiemens per centimeter

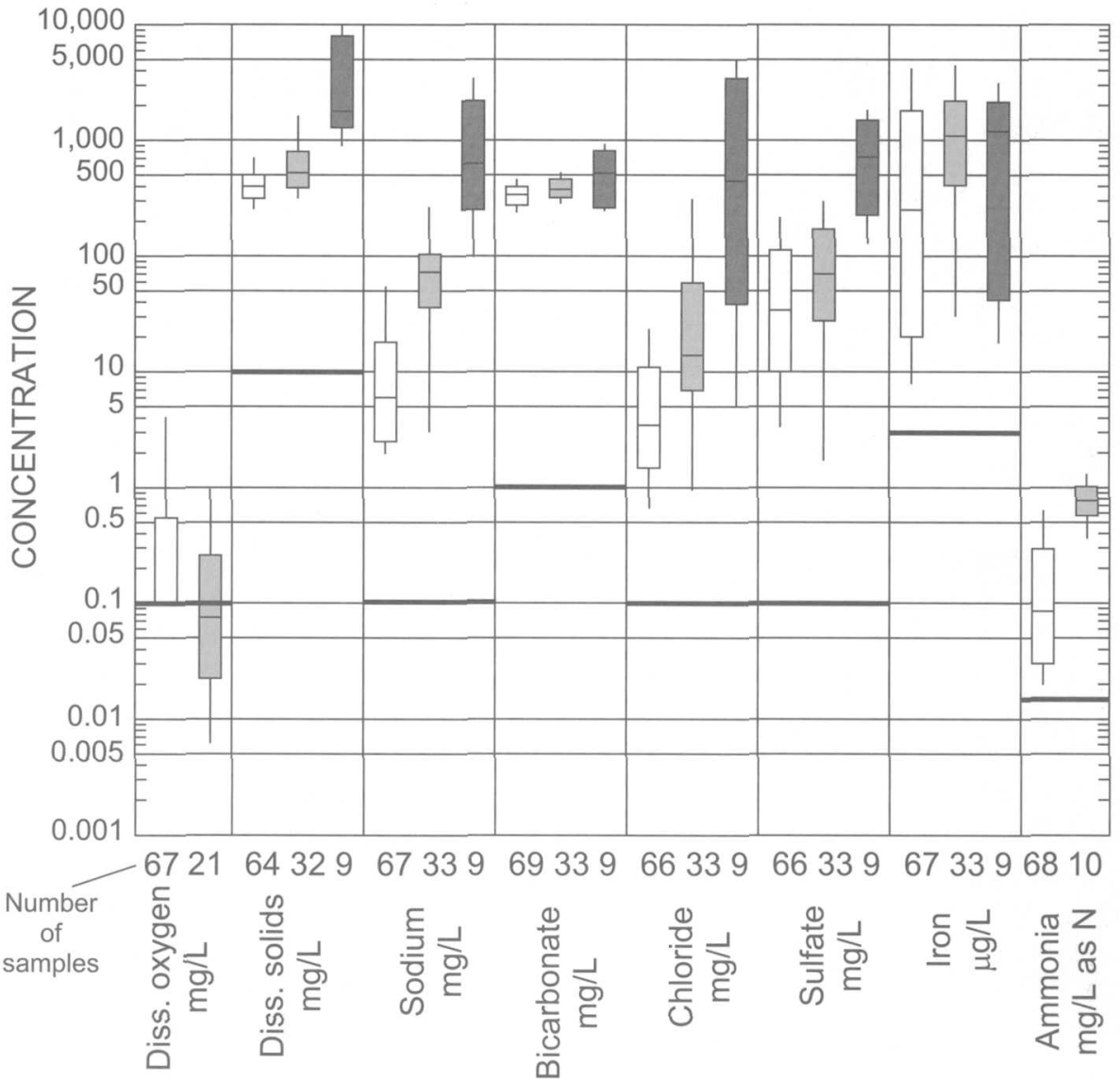

\section{EXPLANATION}

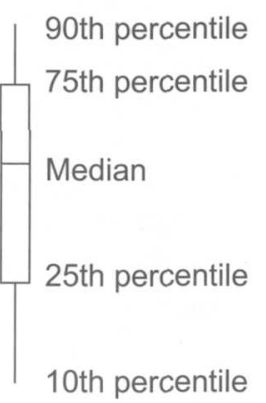

Aquifer Type

$\square$ Surficial

$\square$ Buried glacial

Cretaceous *

- Reporting limit

Percentiles below the reporting limit are extrapolated using probabilityplot regression (Helsel and Hirsch, 1992);

(mg/L, milligrams per liter; $\mu \mathrm{g} / \mathrm{L}$, micrograms per liter; $\mathrm{N}$, nitrogen; diss., dissolved; *, too few samples to accurately characterize these aquifers)

Figure 7. Concentration of selected constituents by aquifer type. 


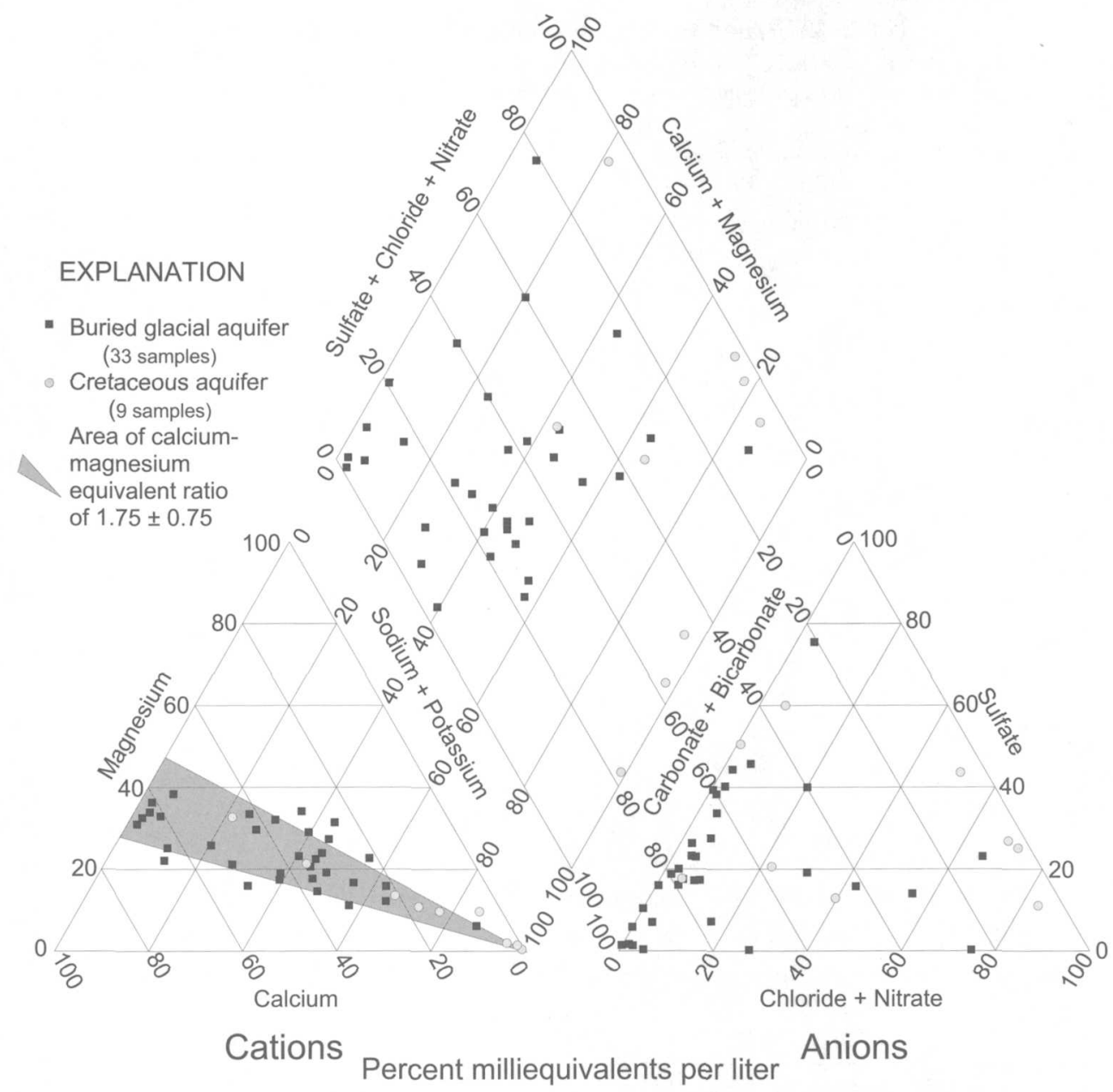

Figure 8. Major-ion composition of waters in shallow buried aquifers.

In waters in surficial aquifers as a whole, 7 pesticides were detected (fig. 5). Fourteen percent of waters contained atrazine, the most commonly detected pesticide. One and one-half percent of waters contained malathion and metribuzin, the least commonly detected pesticides. However, pesticide analyses have reporting limits that range from $0.001 \mu \mathrm{g} / \mathrm{L}$ to $0.035 \mu \mathrm{g} / \mathrm{L}$, and analytical recoveries were variable among pesticides. Therefore, detection percentages are skewed toward pesticides with low reporting limits and high analytical recoveries. Detection percentages standardized to a common reporting limit and corrected for mean analytical recoveries allow fair comparisons among pesticides. At a common reporting limit of $0.1 \mu \mathrm{g} / \mathrm{L}$, waters in surficial aquifers contained 3 detectable pesticides: 1.5 percent of waters contained detectable atrazine, 3.1 percent of waters contained detectable deethylatrazine, and 3.1 percent of waters contained detectable bentazon. Pesticides were analyzed in only 5 of 33 samples from buried glacial aquifers and 6 of 9 samples from Cretaceous aquifers. No pesticides were detected in any of the 11 samples from these shallow buried aquifers.

\section{Evaluation of Ground-Water-Quality Differ- ences}

Waters in surficial aquifers in the Red River Basin varied by physiographic area. Generally, waters in the Drift Prairie and
Lake Plain surficial aquifers contained higher concentrations of dissolved solids than did those in the Moraine area, but other differences between the areas also were substantial. These waterquality differences relate to differences in land use, geology, upward movement of bedrock water, and ground-water recharge among the physiographic areas. Waters in shallow buried glacial aquifers contained higher concentrations of dissolved solids than did waters in surficial aquifers, but contained lower ammonia concentrations and no detected pesticides. These water-quality characteristics relate to ground-water residence time and the presence of a confining bed (both are generally associated with depth). One mechanism that can help explain the water quality in buried glacial aquifers is the mixing of downward-moving waters from surficial aquifers which contain pesticides, high ammonia concentrations, and low dissolved-solids concentrations, with upward-moving bedrock waters which contain no pesticides, low ammonia concentrations, and high dissolved-solids concentrations.

\section{Water-Quality Differences in Surficial Aquifers by Physiographic Area}

Precipitation or snow melt, low in dissolved solids, can acquire chemicals present in the air or applied to the land surface. 
In the absence of a confining bed, this water can percolate to the water table readily. Therefore, surficial aquifers generally contain water that is low in dissolved-solids concentrations, and is susceptible to contamination from land uses. These are the major water-quality characteristics of surficial aquifers in the Red River Basin.

Lorenz and Stoner (1996) reported that land use varies across the basin. In the Moraine area, land use is a mosaic of field agriculture with extensive areas of wetlands, lakes, and forests. Land use in the Lake Plain area is almost entirely field agriculture. Land use in the Drift Prairie area is dominated by field agriculture, but areas of range land are also substantial. Field agriculture is the land use in all three physiographic areas for which chemical application is most intense. Among field-agricultural areas, nutrient application rates are highest in the Lake Plain area (Tornes and Brigham, 1994). Corn, a crop for which triazine use is high, is grown primarily in the southern and eastern parts of the Red River Basin. In North Dakota in 1991, corn was planted on 2.7 percent of the Drift Prairie area and 6.8 percent of the Lake Plain area (Wiyatt and Hamlin, 1992). Lorenz and Stoner (1996) also note that soils over Moraine area surficial aquifers are the most coarse grained, allowing for relatively rapid infiltration of precipitation.

These land-use and soil characteristics help explain the pesticide concentration differences in waters from surficial aquifers. Among waters containing pesticides, both the average summed and median pesticide concentrations were highest in waters from Lake Plain surficial aquifers (table 3). However, pesticides were least frequently detected in aquifers in this area. The Lake Plain area contained the largest proportion of area devoted to field agriculture, particularly corn production, and therefore probably has the highest pesticide use rate. However, Lake Plain area soils developed in relatively fine-grained lake deposits and contain more clay particles that can adsorb pesticides and retard percolation of ground-water recharge, resulting in more time for pesticide degradation. As a result, pesticides reached the water table in relatively few locations, but where they do, pesticide concentrations are relatively high.

The Moraine area had the highest number of different pesticides detected and the highest proportion of waters containing pesticides in surficial aquifers (table 3). The Moraine area's coarse-grained soils and southern location of surficial aquifers (fig. 1) help explain the common occurrence of pesticides in this area. The location of many surficial aquifers in the southern part of both the Lake Plain and Moraine areas is likely responsible for the fact that about 90 percent of all pesticides detected in these areas were triazines. Corn, treated with triazine herbicides, is a major crop above surficial aquifers in the southern part of the study area because the growing season is relatively long and irrigation water is readily available. Bentazon, a selective broadleaf herbicide used in most grass and legume crops (Montgomery, 1993), was found in all three physiographic areas, but accounted for most of the herbicide concentrations in waters from surficial aquifers in the Drift Prairie area. This probably results from less corn production in the area, and hence less triazine applied. As a result, bentazon was a larger proportion of all herbicides applied in the Drift Prairie area.

Unlike pesticides, nutrient concentrations, in the form of nitrate and nitrite, were lowest in waters from surficial aquifers of the agriculturally intense Lake Plain area (table 2, fig. 3). Phosphorus concentrations in waters from the Moraine surficial aquifers were also significantly higher than in waters from the Lake Plain aquifers (table 2). For nitrate and nitrite, soil permeability may influence concentrations more than land use. Soils and aquifer maps (Lorenz and Stoner, 1996) show that aquifers in the Lake Plain generally have lower permeability than do those in the Drift Prairie and Moraine areas, allowing slower percolation of recharge water and more time for denitrification to occur in the soil zone (Cowdery, 1997).

The differences in the major-ion composition between waters from surficial aquifers in the Drift Prairie and Lake Plain areas and waters from the Moraine surficial aquifers are attributed to differences in upward movement of deep bedrock water. Deep bedrock and cretaceous aquifers containing sodium-chloride waters high in dissolved-solids concentrations lie beneath glacial deposits in an area mostly west of the Red River (Lorenz and Stoner, 1996; fig. 1). Where they move upward, waters from deep bedrock aquifers can mix with water low in dissolved-solids concentrations recharging from the land surface, and increase the concentration of major ions in surficial aquifers. Within the Red River Basin study unit, the deepest bedrock aquifers of the Williston Basin, containing waters highest in dissolved-solids concentrations (Stoner and others, 1993), subcrop farthest east because of the westward dip of the sedimentary strata. Therefore, waters in the Lake Plain surficial aquifers had the highest concentrations of major ions, reflecting upward movement from these deepest aquifers. Water in the Moraine surficial aquifers had the lowest concentrations of dissolved solids partly because this area is underlain by impermeable crystalline bedrock. The coarser-grained soils in the Moraine area also help explain why its waters were low in dissolved-solids concentrations because faster percolation of recharge water allows less time to dissolve materials in the unsaturated zone.

\section{Water-Quality Differences Between Surficial and Shallow Buried Aquifers}

In contrast to that in surficial aquifers, water quality in shallow buried aquifers in the Red River Basin indicates that these aquifers had not been substantially affected by land uses. Confining beds transmit water from the land surface very slowly, resulting in relatively long residence times. Nutrients were analyzed in 16 of 42 samples from shallow buried aquifers. The only nutrient found in appreciable concentrations in waters from these aquifers was ammonia (medians of 0.77 and $2.5 \mathrm{mg} / \mathrm{L}$ as nitrogen, for water in buried glacial and Cretaceous aquifers respectively, table 4). Nitrate was below the detection limit of $0.05 \mathrm{mg} / \mathrm{L}-\mathrm{N}$ in all but 5 samples. Excluding one high-concentration sample $(17 \mathrm{mg} /$ L-N nitrate) that may be contaminated due to poor well construction, concentrations of nitrate above the detection limit ranged from $0.065-0.65 \mathrm{mg} / \mathrm{L}-\mathrm{N}$. Waters in shallow buried aquifers 
were more anoxic than waters in surficial aquifers so higher concentrations of the reduced form of nitrogen (ammonia) is reasonable. The lack of oxygen in deeper ground water resulted from its long travel time. During this time, it was isolated from the atmosphere and most oxygen and oxidized forms of nitrogen (nitrate and nitrite) that may have been in the waters when they were recharged were removed through oxidation of organic matter or minerals. The nitrogen in nitrate was probably reduced to ammonia. The lack of any detected pesticide and the low concentration of nitrate in samples from buried glacial aquifers suggests that the overlying confining beds may protect aquifers from land-use effects on water quality by retarding the movement of recharge water to these aquifers. Slow recharge velocities allow time for contaminants to be sorbed or degraded before they reach waters in buried aquifers. Recharge velocities may be so slow that recently applied chemicals have not yet reached these aquifers. However, dilution of water containing pesticides and nitrate moving downward from surficial aquifers with water containing no pesticides and nitrate moving upward from deep bedrock aquifers can also help explain the lack of these chemicals found in waters from shallow buried aquifers.

The high concentrations of major ions found in waters from Cretaceous aquifers reflect the long time these waters had been in contact with dissolvable aquifer material. For example, the main recharge areas of the aquifers in the Dakota Formation (Lower Cretaceous) are in western North Dakota and eastern Montana and ground-water-residence times are on the order of thousands of years (Downey, 1986). Concentrations of major ions in waters from buried glacial aquifers were commonly intermediate to concentrations in Cretaceous and surficial aquifers, but tended much closer to that in surficial aquifers (table 4, compare figs. 4 and 8).

In general, waters in both Cretaceous aquifers (very sodiumrich, calcium-magnesium poor, and high in dissolved-solids concentrations) and waters in surficial aquifers (sodium-poor, calcium-magnesium rich, and low in dissolved-solids concentrations) had a $1.75 \pm 0.75$ calcium-magnesium ratio, regardless of anionic composition. Waters in buried glacial aquifers ranged between the cationic compositions and dissolved-solids concentrations of waters in surficial and Cretaceous aquifers. This pattern suggests that calcium-magnesium dominated waters in surficial aquifers mix with sodium dominated waters in Cretaceous and deep bedrock aquifers to produce the cationic composition of the waters in buried glacial aquifers. The pattern of upward flow from bedrock aquifers is consistent with the regional flow that Downey (1986) described for these aquifers in the northern Great Plains.

Table 5. U.S. Environmental Protection Agency drinking-water standards and health advisories exceeded in the Red River of the North Basin ground water

MCL, maximum contaminant level; blank cell, no standard or advisory exists; N, nitrogen; / separates first standard percentage from second; shaded areas: too few samples to statistically characterize aquifer group]

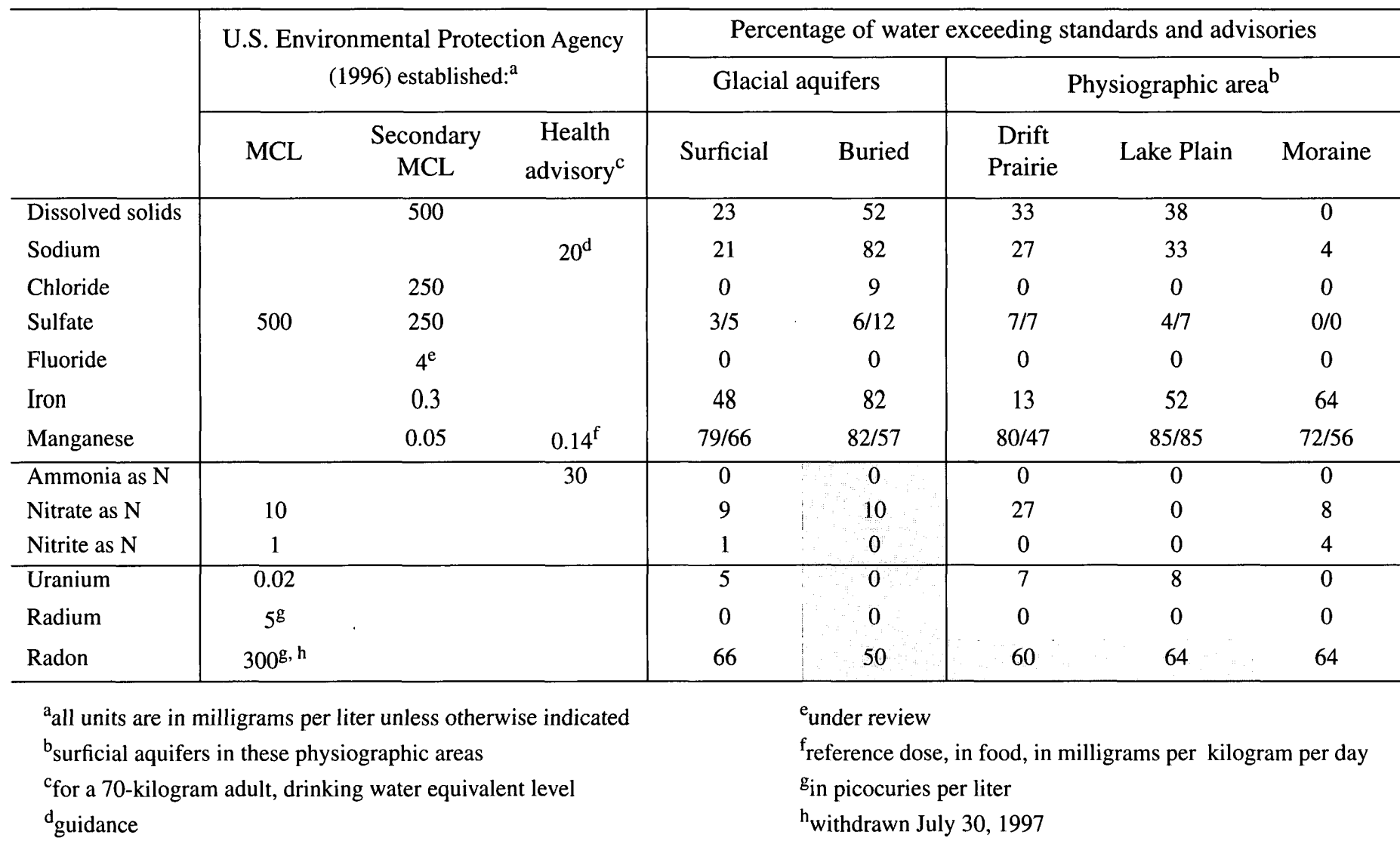




\section{Drinking-Water Implications}

Ground water is an important source of water throughout the Red River Basin. Stoner and others (1993) reported that in 1990, 53 percent of the $72 \mathrm{Mgal} / \mathrm{d}$ of water used for domestic and public supply in the Basin was ground water. Ground water also provided 51 percent of the $196 \mathrm{Mgal} / \mathrm{d}$ of all water used. Residents living in the vast majority of the Red River Basin area rely on aquifers to supply water. The quality of ground water in a given part of the Red River Basin affects both how that water can be used and how that part of the basin can be used.

Waters in surficial aquifers was of good natural quality and low in dissolved-solids concentrations (median: $400 \mathrm{mg} / \mathrm{L}$ ). However, surficial aquifers cover only 11 percent of the basin area and they are at risk of contamination from land uses. Some of this water exceeded the USEPA's secondary maximum contaminant levels (SMCL, U.S. Environmental Protection Agency, 1996; table 5) for dissolved solids (23 percent), manganese (79 percent), and iron ( 48 percent), but these standards are set primarily for aesthetic reasons and their exceedence does not seriously restrict water use. Water in the basin that contains high concentrations of dissolved solids is usually hard and can require the use of more soap and can leave mineral deposits. Water containing high concentrations of iron and manganese can stain utensils or clothing. Sixty-six percent of waters from Moraine surficial aquifers exceeded the USEPA's drinking-water maximum contaminant level (MCL) of 300 picocuries per liter (pCi/L) for radon (the enforceable concentration limit for public water supplies), but this standard was withdrawn in 1997 (table 5). Wanty and Nordstrom (1993) note that ground-water radon concentrations are usually in the range of hundreds or thousands of $\mathrm{pCi} / \mathrm{L}$. Nitrate, commonly derived from agricultural application of fertilizers, exceeded the USEPA nitrate MCL of $10 \mathrm{mg} / \mathrm{L}-\mathrm{N}$ in 9 percent of waters from surficial aquifers in all physiographic areas studied and in 27 percent of waters from surficial aquifers in the Drift Prairie physiographic area. Ground water in the Red River Basin exceeded none of the 13 MCLs that have been established for the pesticides analyzed.

Concentrations of agricultural chemicals higher than reported herein have been measured in surficial aquifers in the Red River Basin. In a more detailed associated study, 29 water samples in the upper several feet of the surficial aquifer in the Otter Tail outwash land-use study area (fig. 1) were collected. Results showed that 43 percent of this water exceeded the USEPA nitrate MCL of $10 \mathrm{mg} / \mathrm{L}-\mathrm{N}$ and 76 percent of this water contained detectable pesticides (Cowdery, 1997). This aquifer was chosen for detailed study because land-use and hydrogeological conditions made it among the most susceptible in the Red River Basin to land-use contamination. Intense, irrigated agriculture, coarse-grained soils, and oxygenated ground-water conditions combined to promote the transport of agricultural chemicals to the water table. In the Otter Tail outwash aquifer, nitrate concentrations decreased with depth below the water table over several feet. Results from the Otter Tail outwash study do not directly relate to drinkingwater concerns because most drinking-water wells are screened in the lower part of an aquifer. The fact that wells sampled in the
Drift Prairie physiographic area had the shallowest screen depth below the water table (fig. 2) may explain why nitrate concentrations in waters from surficial aquifers in this area were comparatively high. The limited areal extent of surficial aquifers, and their susceptibility to nitrate contamination, particularly in the Drift Prairie area, restrict their usefulness as sources of drinking water (27 percent exceed the nitrate MCL), but they are useful for other purposes such as irrigation.

Samples of water from buried glacial aquifers contained no detectable pesticides and generally low concentrations of nutrients. However, much of the water in these aquifers exceeded the USEPA SMCLs for dissolved solids (52 percent), iron ( 82 percent), and manganese ( 82 percent) (table 5). Additionally, many waters in buried glacial aquifers exceeded USEPA health advisories (HA) for sodium ( 82 percent) and manganese (57 percent). These advisories are concentrations below which no adverse health effects are likely to occur when water is consumed over a lifetime. People who should restrict sodium or manganese in their diet should be aware that substantial amounts of these elements can come from water withdrawn from buried glacial aquifers. The USEPA HA for manganese was also exceeded by 66 percent of waters from surficial aquifers. Data from this study confirm earlier findings (Stoner and others, 1993) that waters in buried glacial aquifers and, to a lesser degree waters in surficial aquifers, are, in places, affected by the upward movement of saline ground waters from deep bedrock aquifers. Sodium concentrations in waters from buried glacial aquifers, for example, only exceed 150 $\mathrm{mg} / \mathrm{L}$ (an arbitrary concentration) where they are underlain by bedrock aquifers in the western one-half of the Red River Basin (fig. 1). There is a similar pattern of high concentrations in the western part of the basin for dissolved solids, calcium, sulfate, and chloride. Further, it is likely that the deeper the buried glacial aquifer is, the more it will be influenced by upward movement of water from bedrock aquifers. For most areas of the Red River Basin, however, waters in buried glacial aquifers may be the best available source of drinking water because these aquifers are protected from land-use contamination by confining beds. The quality of water in these aquifers can only be affected by the upward movement of water with high dissolved solids concentrations in the Drift Prairie and Lake Plain physiographic areas.

\section{Summary}

Differences in land use, geology, and the upward movement of water from bedrock aquifers in three physiographic areas of the Red River Basin during 1991-95 produced differences in the quality of water in surficial aquifers in these areas. In general, water in surficial aquifers in these areas were fairly low in dissolved solids (median: $400 \mathrm{mg} / \mathrm{L}$ ) and of good drinking-water quality. The quality of waters from the Drift Prairie and Lake Plain areas were similar and had statistically significantly higher concentrations of dissolved solids, sodium, potassium, sulfate, fluoride, silica, and uranium than did waters from the Moraine area. Radium, iron, nitrate and nitrite concentrations were significantly different among physiographic areas. Pesticides were found in 52 percent of waters from surficial aquifers in the 
Moraine area, but only in 20 percent and 12 percent of waters from the Drift Prairie and Lake Plain areas, respectively. Triazine herbicides and their metabolites composed 89 percent and 90 percent of summed pesticide concentrations in waters from the Lake Plain and Moraine aquifers respectively. Bentazon accounted for 94 percent of summed pesticide concentration in waters from the Drift Prairie area. Triazines and bentazon accounted for 98 percent of summed pesticide concentrations in waters from all surficial aquifers. The DDT metabolite $p, p^{\prime}$-DDE was found at very low concentrations $(0.002 \mu \mathrm{g} / \mathrm{L})$ in waters from the Lake Plain and Moraine surficial aquifers. Twenty-three of 36 samples from surficial aquifers in the Lake Plain and Moraine areas exceeded the USEPA drinking-water Maximum Contaminant Level (withdrawn in 1997) of $300 \mathrm{pCi} / \mathrm{L}$ for radon.

A survey of water quality in buried glacial aquifers in a 90mile-wide band across the central one-third of the Red River Basin during 1991-95 showed that waters in these aquifers had statistically higher concentrations of dissolved solids, sodium, potassium, bicarbonate, chloride, fluoride, and iron, but not calcium, magnesium, silica, manganese, nitrate, or nitrite, than did waters in surficial aquifers. In nine samples from Cretaceous aquifers, concentrations of these significantly different constituents were as high as, and usually much higher than, concentrations in waters from buried glacial aquifers. Regardless of anionic composition, all ground waters sampled for this study had calcium-magnesium ratios of about $1.75 \pm 0.75$, although water from Cretaceous aquifers was dominated by sodium. This pattern suggests that calcium-and-magnesium dominated waters in surficial aquifers mix with sodium dominated waters from bedrock aquifers to produce the cationic composition of waters in buried glacial aquifers. No pesticides were detected in five samples from buried glacial aquifers or six samples from Cretaceous aquifers.

Agricultural land-use patterns and soil texture in the three studied physiographic areas can explain the types and concentrations of pesticide found in waters in surficial aquifers. Soil texture best explains nutrient concentrations in waters from these aquifers. Rapid recharge accounts for the relatively low concentrations of major ions found in waters in surficial aquifers regardless of physiographic area. Upward movement of deeper ground water high in dissolved solids in areas underlain by bedrock aquifers is responsible for the significantly higher concentrations of some constituents in waters from surficial aquifers in the Drift Prairie and Lake Plain areas relative to that from Moraine aquifers.

The slow rate at which recharge enters shallow buried aquifers through confining beds results in water low in pesticides and nutrients because these contaminants are sorbed or degraded before they can reach buried aquifers or because their use is so recent that they have not yet reached these aquifers. The corresponding long residence time of waters from Cretaceous aquifers accounts for its high major-ion concentrations. Waters in buried glacial aquifers are chemically more similar to waters in surficial aquifers but are, in places, affected by upward movement of bedrock water.
Waters in surficial aquifers in the Red River Basin were of good natural quality, but some exceeded USEPA SMCLs for dissolved solids, iron, and manganese. Twenty-seven percent of water from aquifers in the Drift Prairie area exceeded the USEPA MCL of $10 \mathrm{mg} / \mathrm{L}-\mathrm{N}$ for nitrate, compared to eight percent of that in the Moraine area and none in the Lake Plain area. The limited areal extent of surficial aquifers and their susceptibility to landuse contamination restricts their usefulness as sources of drinking water but not for other uses such as irrigation. Waters in buried glacial aquifers contained low nutrient concentrations and no pesticides but many exceeded USEPA HAs for dissolved solids, sodium, and manganese. Sixty-six percent of water from surficial aquifers exceeded the USEPA HA for manganese. Although too few samples from buried glacial aquifers were collected to statistically characterize them by physiographic area, areas where waters high in dissolved-solids concentrations move upward from bedrock aquifers in the western one-half of the Red River Basin coincide with areas where waters in buried glacial aquifers contain high concentrations of constituents such as dissolved solids, calcium, sulfate, and chloride. It is also likely that deeper glacial aquifers are affected by the upward movement of bedrock waters more than shallower aquifers. For most areas of the Red River Basin, buried glacial aquifers may be the best source of drinking water.

\section{References}

Armstrong, C.A., 1982, Ground water resources of Ransom and Sargent Counties, North Dakota: North Dakota Geological Survey Bulletin 69-Part III, 51 p., 2 plates.

American Society for Testing and Materials, 1996a, Annual book of ASTM standards, section 11: Water and Environmental Technology, v. 11.02, D5174-91, p. 699-701.

1996b, Annual book of ASTM standards, section 11: Water and Environmental Technology, v. 11.02, D5072-92, p. 674676.

Baker, Jr., C.H., and Paulson, Q.F., 1967, Geology and ground water resources Richland County, North Dakota, Part III, Ground Water Resources: North Dakota Geological Survey Bulletin 46, 47 p.,1 plate.

Cowdery, T.K., 1997, Shallow ground-water quality beneath cropland in the Red River of the North Basin, Minnesota and North Dakota, 1993-95: U.S. Geological Survey Water-Resources Investigation Report 97-4001, 52 p.

Downey, J.S., 1986, Geohydrology of bedrock aquifers in the Northern Great Plains in parts of Montana, North Dakota, South Dakota, and Wyoming: U.S. Geological Survey Professional Paper 1402-E, $87 \mathrm{p}$.

Faires, L.M., 1993, Methods of analysis by the U.S. Geological Survey National Water-Quality Laboratory-Determination of metals in water by inductively coupled plasma-mass spectrometry: U.S. Geological Survey Open-File Report 92-634, $28 \mathrm{p}$. 
Fishman, M.J., ed., 1993, Methods of analysis by the U.S. Geological Survey National Water Quality Laboratory-Determination of inorganic and organic constituents in water and fluvial sediments: U.S. Geological Survey Open-File Report 93-125, $217 \mathrm{p}$.

Gilliom, R.J., Alley, W.M., and Gurtz, M.E., 1995, Design of the National Water-Quality Assessment program-Occurrence and distribution of water-quality conditions: U.S. Geological Survey Circular 1112, 33 p.

Helsel, D.R. and Hirsch, R.M., 1992, Statistical methods in water resources: Elsevier Science Publishers B.V., Amsterdam, The Netherlands, $522 \mathrm{p}$.

Koterba, M.T., Wilde, F.D., and Lapham, W.W., 1995, Groundwater data-collection protocols and procedures for the $\mathrm{Na}$ tional Water-Quality Assessment Program-Collection and documentation of water-quality samples and related data: U.S. Geological Survey Open-File Report 95-399, 113 p.

Lapham, W.W., Wilde, F.D., and Koterba, M.T., 1995, Groundwater data-collection protocols and procedures for the $\mathrm{Na}$ tional Water-Quality Assessment Program-Selection, installation, and documentation of wells, and collection of related data: U.S. Geological Survey Open-File Report 95398,69 p.

Lindgren, R.J., 1996, Availability and quality of water from drift aquifers in Marshall, Pennington, Polk, and Red Lake Counties, northwestern Minnesota: U.S. Geological Survey WaterResources Investigations Report 95-4201, 144 p.

Lorenz, D.L., and Stoner, J.D., 1996, Sampling design for assessing water quality of the Red River of the North Basin, Minnesota, North Dakota, and South Dakota, 1993-1995: U.S. Geological Survey Water-Resources Investigations Report 96-4129, 2 sheets.

Menheer, M.A., and Brigham, M.E., 1997, National Water-Quality Assessment Program-Ground-water sampling methods and quality control for the Red River of the North Basin, 1993-1995: U.S. Geological Survey Water-Resources Investigations Report 96-4317, 34 p.

Montgomery, J.H., 1993, Agrochemical desk reference: Lewis Publishers, Chelsea, U.S.A., p. 46.

Rose, D.L., and Schroeder, M.P., 1995, Methods of analysis by the U.S. Geological Survey National Water Quality Laboratory-Determination of volatile organic compounds in water by purge and trap capillary gas chromatography/mass spectrometry: U.S. Geological Survey Open-File Report 94-708, $26 \mathrm{p}$.
Scott, J.C., 1990, Computerized stratified random site-selection approaches for design of a ground-water-quality sampling network: U.S. Geological Survey Water-Resources Investigations Report 90-4101, 109 p.

Stoner, J.D., Lorenz, D.L., Wiche, G.J., and Goldstein, R.M., 1993, Red River of the North Basin, Minnesota, North Dakota, and South Dakota: Water Resources Bulletin, v. 29, no. 4, p. 575-615.

Tornes, L.H. and Brigham, M.E., 1994, Nutrients, suspended sediment, and pesticides in waters of the Red River of the North Basin, Minnesota, North Dakota, and South Dakota, 19701990: U.S. Geological Survey Water-Resources Investigation Report 93-4231, 62 p.

U.S. Environmental Protection Agency, 1980, Prescribed procedures for measurement of radioactivity in drinking water, Method 903.0: EPA-600/4-80-032, Cincinnati, Ohio, p. 3137.

1996, Drinking water regulations and health advisories: U.S. Environmental Protection Agency, 11 p.

Wanty, R.B., and Nordstrom, D.K., 1993, Natural radionuclides, in Alley W.M., ed., Regional Ground-Water Quality: Van Nostrand Reinhold, New York, New York, p. 423-441.

Werner, S.L., Burkhardt, M.R., and DeRusseau, S.N., 1996, Methods of analysis by the U.S. Geological Survey National Water Quality Laboratory-Determination of pesticides in water by carbopak-b solid-phase extraction and high-performance liquid chromatography: U.S. Geological Survey Open-File Report 96-216, 42 p.

Wiyatt, S.D., and Hamlin, W.G., 1992, North Dakota agricultural statistics 1992: North Dakota State University Agriculture Statistics No. 61, 112 p.

Winter, T.C., Bidwell, L.E., and Maclay, R.W., 1969, Water resources of the Otter Tail River watershed west-central Minnesota: U.S. Geological Survey Hydrologic Investigations Atlas HA-296, 4 sheets.

Zaugg, S.D., Sandstrom, M.W., Smith, S.G., and Fehlberg, K.M., 1995, Methods of analysis by the U.S. Geological Survey National Water Quality Laboratory-Determination of pesticides in water by $\mathrm{C}-18$ solid-phase extraction and capillarycolumn gas chromatography/mass spectrometry with selected-ion monitoring: U.S. Geological Survey Open-File Report $95-181,49 \mathrm{p}$. 
